\title{
ARTICLES
}

\section{DEFAULT RULES, WEALTH DISTRIBUTION, AND CORPORATE LAW REFORM: EMPLOYMENT AT WILL VERSUS JOB SECURITY}

\author{
DAVID MILLON $†$
}

\section{INTRODUCTION}

In recent years, a number of commentators have criticized corporate law's traditional commitment to shareholder primacy because of the costs it imposes on nonshareholder corporate constituencies. The phrase "shareholder primacy" refers to management's legal duty to pursue shareholder wealth maximization without regard for competing considerations. Despite the jarring social effects of the hostile takeover craze of the 1980 s, shareholder primacy has weathered those storms and has managed to retain its status as corporate law's foundational principle. ${ }^{1}$ Adherence to this norm can result in decisions that are harmful to various corporate constituencies, including workers, lenders, suppliers, and others involved with the corporation. For example, seeking to maintain or enhance corporate profits for shareholders may prompt management to lay off workers or close production facilities. Such decisions can cause disastrous consequences for those who lose their jobs, as well as further harmful ripple effects

† Professor of Law, Washington and Lee University. Ph.D. 1982, Cornell University; J.D. 1983, Harvard University. The author appreciates generous assistance and advice from Bill Bratton, Art Goldsmith, Lyman Johnson, Karl Kaiser, Russell Korobkin, Joe McCahery, Larry Mitchell, and Blake Morant, as well as financial support from the Frances Lewis Law Center, Washington and Lee University.

'See, e.g., Paramount Communications Inc. v. QVC Network Inc., 637 A.2d 34, 48 (Del. 1994) (holding that, when a corporation undertakes a transaction that will cause "a change in corporate control" or "a break-up of the corporate entity, the directors' obligation is to seek the best value reasonably available to the stockholders"). Shareholder primacy retains its foundational status despite recent legislative developments appearing to point in a new direction. See infra notes 15-22 and accompanying text. For a fuller discussion of recently enacted "directors' duty" statutes that authorize directors to consider nonshareholder constituents in decisionmaking, see generally David Millon, Redefining Corporate Law, 24 IND. L. REV. 223 (1991). 
within the local community and beyond. ${ }^{2}$ Similarly, management may engage in activities beneficial to shareholders that increase the default risk faced by the corporation's creditors. ${ }^{3}$ In these and other ways, nonshareholder corporate constituencies are vulnerable to actions taken by corporate managers for the benefit of shareholders.

Scholars who have expressed concern about the social costs of shareholder primacy have been labeled "communitarians." Applied to corporate law scholarship, the term seems to have originated as a pejorative designation deployed by defenders of the shareholder primacy status quo. ${ }^{4}$ In fact, among the critics of shareholder primacy, it is hard to find a core set of premises that are distinctively communitarian. Little effort has been made to forge links to the rich and extensive philosophical literature on communitarianism. ${ }^{5}$ Corporate law communitarians seem to be united primarily by their critical posture.

The common thread in this diverse body of work has been the effort to replace traditional shareholder primacy with a new legal regime-one that is more responsive to the problem of nonshareholder vulnerability to the social costs generated by corporate law's traditional commitment to shareholder wealth maximization. ${ }^{6}$ Some writers have characterized the corporation as a community of interrelated, interdependent constituencies, and then drawn various norma-

${ }^{2}$ For a compelling discussion of the social costs of plant closings and other exercises in "downsizing," see THE DOWNSIZING OF AMERICA (New York Times ed., 1996).

${ }^{3}$ See, e.g., Metropolitan Life Ins. Co. v. RJR Nabisco, Inc., 716 F. Supp. 1504, 1506 (S.D.N.Y. 1989) (involving allegations that corporate executives "drastically impaired the value of [corporate] bonds... by ... misappropriating the[ir] value" to help finance a leveraged buyout).

4 See Michael E. DeBow \& Dwight R. Lee, Shareholders, Nonshareholders and Corporate Law: Communitarianism and Resource Allocation, 18 DEL. J. CORP. L. 393, 395 (1993) (labeling critics of shareholder primacy "communitarians" because they favor a "public law" conception of corporate law).

${ }^{5}$ Ironically, the most thorough attempt to draw on the philosophical literature has been the remarkable article by Professor Cox, who is a critic-though an unusually thoughtful and sympathetic one-of the communitarian turn in corporate law scholarship. See Paul N. Cox, The Public, the Private and the Corporation, 80 MARQ. L. REV. 391 (1997) (seeking to clarify the premises and implications of both contractarian and communitarian theories).

${ }^{6}$ For a general discussion, see David Millon, Communitarianism in Comporate Law: Foundations and Law Reform Strategies, in PROGRESSIVE CORPORATE LAW 1 (Lawrence E. Mitchell ed., 1995) [hereinafter Millon, Communitarianism]. For a bibliography of scholarship in a more or less communitarian mode, see David Millon, Communitarians, Contractarians, and the Crisis in Corporate Law, 50 WASH. \& LEE L. REV. 1373, 1391-93 (1993) [hereinafter Millon, Crisis in Corporate Law]. 
tive conclusions from this descriptive claim. ${ }^{7}$ Others have relied on rhetoric and analytical tools of neoclassical economics as the basis for concrete law reform proposals. ${ }^{8}$ What brands the latter writers "communitarian" is their attention to issues that traditionally have been excluded from corporate law discourse. Their wider conception of the appropriate scope for corporate law reflects a view of the corporation as a community of interests embracing more than just shareholders and managers. Although the movement as a whole might be better termed "progressive" than "communitarian," the latter term has gained currency and, if nothing else, is sufficiently broad and amorphous to warrant continued usage.

The communitarian perspective stands in contrast to the contractual or contractarian model of the corporation. According to the contractarian position, ${ }^{10}$ the corporation is nothing more than a

7 See, e.g., Millon, Crisis in Comporate Law, supra note 6; Lawrence E. Mitchell, A Theoretical and Practical Framework for Enforcing Corporate Constituency Statutes, 70 TEx. L. REv. 579 (1992) [hereinafter Mitchell, Theoretical and Practical Framework]; Lawrence E. Mitchell, The Faimess Rights of Corporate Bondholders, 65 N.Y.U. L. REV. 1165 (1990) [hereinafter Mitchell, Fairness Rights of Corporate Bondholders]; Lawrence E. Mitchell, Trust. Contract. Process., in PROGRessive CORPORATE LAW, supra note 6, at 185 [hereinafter Mitchell, Trust. Contract. Process.]; Lyman Johnson, Individual and Collective Sovereignty in the Corporate Enterprise, 92 COLUM. L. REV. 2215 (1992) (reviewing ROBERT N. BELlaH ET AL., THE GOOD SOCIETY (1991), and FRANK H. EASTERBROOK \& DANIEL R. FISCHEL, THE ECONOMIC STRUCTURE OF CORPORATE LAW (1991)).

${ }^{8}$ See, e.g., William W. Bratton, Game Theory and the Restoration of Honor to Corporate Law's Duty of Loyaliy, in PROGRESSIVE CORPORATE LAW, supra note 6, at 139; Morey W. McDaniel, Stockholders and Stakeholders, 21 STETSON L. REV. 121 (1991); Marleen A. O'Connor, The Human Capital Era: Reconceptualizing Comporate Law to Facilitate LaborManagement Cooperation, 78 CORNELL L. REV. 899 (1993).

9 "Progressive" can imply a commitment to social progress (admittedly a contestable concept) or an interest in "new ideas, inventions, or opportunities." WEBSTER's THIRD NEW INTERNATIONAL DICTIONARY 1813 (Philip Babcock Gove ed., 1981). For a collection of essays by self-identified progressive corporate law scholars revealing their characteristic breadth in normative stance and in willingness to look to novel ideas for guidance, see generally PROGRESSIVE CORPORATE LAW, supra note 6.

${ }^{10}$ The most comprehensive statement of the contractarian position is EASTERBROOK \& FISCHEL, supra note 7. For a concise overview, see Henry N. Butler, The Contractual Theory of the Corporation, GEO. MASON L. REV., Summer 1989, at 99. A complete list of scholars influenced by contractarian theory would include most of the more prominent scholars in the corporate law field. This is a measure of the extent to which the contractarian perspective currently dominates academic corporate law discourse. See William T. Allen, Contracts and Communities in Corporation Law, 50 WASH. \& LEE L. REV. 1395, 1400 (1993) (asserting the contractarian model to be the "dominant legal academic view"). Contractarianism has been significantly less influential among judges and legislators, but no less influential than communitarianism. The contractarian phenomenon represents the manifestation in one field of the pervasive general influence of neoclassical economics on legal scholarship during the last 20 or so years. When thinking about law and economics in the field of corporate 
nexus of contracts among the various suppliers of inputs (capital, labor, credit, materials, and the like) to the production process. The parties to these various contracts define their respective rights and duties either through ad hoc bargaining that is more or less transaction-specific, or through acceptance of standard-form provisions that are typically taken "off the rack." Examples of the former include collective bargaining agreements and bond indentures, while the terms provided by state corporate law-the body of statutory and judge-made doctrine that defines the rights of shareholdersexemplify the latter. Seen in this light, it makes no sense to speak of shareholders as enjoying a legally mandated privilege in relation to other corporate constituencies. If the rights and duties of the various corporate constituencies are thought of as creations of contract, any benefits or advantages that shareholders enjoy are products of consent by the various affected parties, as are any costs or disadvantages that other constituencies must bear.

According to this view, if relationships among shareholders and nonshareholders are defined by contract, nonshareholders can protect themselves ex ante from the social costs of shareholder wealth maximization by bargaining and paying for provisions that provide the desired safeguards. For example, workers can bargain for job security, or bondholders can bargain for specific protective covenants or more general fiduciary protections. " If they have not done so, it is because they do not believe that such contract terms are worth the price. ${ }^{12}$ Legal reforms aimed at improving the welfare of nonshare-

law, one inevitably thinks about contractarianism. Even recent applications of game theory and network externality theory rest on a contractual conception of the corporation and of corporate law. See, e.g., Jason Scott Johnston, Opting In and Opting Out: Bargaining for Fiduciary Duties in Cooperative Ventures, 70 WASH. U. L.Q. 291 (1992) (applying game theory to contractual analysis of fiduciary-duty law in business associations); Michael Klausner, Corporations, Corporate Law, and Networks of Contracts, 81 VA. L. REV. 757 (1995) (applying the network externality idea to corporate law's contractarian paradigm).

${ }^{11}$ See, e.g., Stephen M. Bainbridge, In Defense of the Shareholder Wealth Maximization Norm: A Reply to Professor Green, 50 WASH. \& LEE L. REV. 1423, 1443 (1993) ("Those nonshareholder constituencies that enter voluntary relationships with the corporation thus can protect themselves by adjusting the contract price to account for negative externalities imposed upon them by the firm."); Jonathan R. Macey, An Economic Analysis of the Various Rationales for Making Shareholders the Exclusive Beneficiaries of Corporate Fiduciary Duties, 21 STETSON L. REV. 23, 36-39 (1991) (stating that nonshareholder constituencies such as workers and bondholders can protect themselves by means of contracts if they are willing to pay for the protection).

${ }^{12}$ See Macey, supra note 11, at 36-39, 36 (" [T] he absence of contractual protection for nonshareholder constituencies may simply reflect the fact that such constituencies 
holders would amount to interference with private ordering and, in the contractarian view, would be illegitimate for that reason. ${ }^{13}$ The contractarian vision of the corporation thus differs from the communitarian stance, both in its descriptive and in its normative aspects.

In this Article, I seek to further the communitarian project by proposing a new law reform strategy. I draw on recent economic research to advance two claims. In Part II, I discuss the relevance of the endowment effect and status quo bias to the distribution of gains from trade in employment contracting. Part III then draws on pathdependency theory to argue that the current prevalence of at-will employment does not necessarily indicate its superiority to job security and, therefore, does not provide a basis for rejecting the change in the law proposed here. Before turning to those matters, however, I consider, in Part $\mathrm{I}$, existing law reform proposals in a communitarian vein. Although these proposals have taken quite different directions and are subject to important shortcomings, I believe they share a valuable foundational commitment. They exemplify an unwillingness to accept the sufficiency of private ordering as a mechanism for nonshareholder protection from the costs of shareholder wealth maximization. In my view, limited wealth imposes significant constraints on the ability of certain nonshareholder constituencies to obtain legitimate safeguards through the bargaining process. I therefore suggest in Part II that altering existing contractual default rules may improve the bargaining capability of nonshareholders. I should stress that this Article is modest in ambition. Even leaving aside the important and controversial political question of whether the law ought to be used for redistributive purposes, there remains the prior question of whether the strategy considered here might actually create any benefits. The question proves to be far more complicated than typically has been assumed. The exploration offered here is therefore tentative and preliminary. ${ }^{14}$

are unwilling to pay for such protection in the form of lower wages or lower interest rates on debt.").

1s See Bainbridge, supra note 11, at 1434 (arguing that, since "nonshareholder constituencies can adequately protect their claims through the contracting and political processes," legal reforms aimed at aiding nonshareholders are "both unnecessary and wholly undeserved"); DeBow \& Lee, supra note 4, at 422-24 ("Whether communitarian legal scholars like it or not, the corporate entity is a contractual entity. Accordingly, corporate law reform cannot succeed if it violates the essentially 'private' nature of the contractual relations at the corporate entity's core. ... [C]ommunitarian advocates of nonshareholder constituency statutes run afoul of this rule.").

14 As such, this Article elaborates on an earlier, even more preliminary exploration in Millon, Communitarianism, supra note 6, at 22-30. 


\section{COMMUNITARIAN LAW REFORM PROPOSALS}

Communitarian corporate law scholars, sympathetic to nonshareholder claims for protection from the costs of shareholder wealth maximization, have developed two general strategies. This Part briefly examines these strategies, concluding that they are subject to important shortcomings. I then suggest a new strategy that respects communitarian misgivings about the adequacy of private ordering while addressing my concerns about existing proposals. My alternative relies more heavily on bargaining than existing proposals have, but within a framework of altered contractual default rules. This approach seeks to redress the problem of "bargaining capability," a concept discussed in Part I.D.1 below. Whether this proposal might actually improve bargaining outcomes is considered in Part II.

\section{A. The Multifiduciary Model}

One law reform strategy, which has been variously termed the "stakeholder,"15 "multifiduciary,"16 "constituency,"17 or "directors' duty" model, would redefine the duties of the corporation's board of directors to include regard for nonshareholder as well as shareholder interests. ${ }^{19}$ Some have drawn inspiration from the new directors' duty

${ }^{15}$ See, e.g., Ronald M. Green, Shareholders as Stakeholders: Changing Metaphors of Corporate Governance, 50 WASH. \& LEE L. REV. 1409, 1411 (1993) ("'[S]takeholder' and 'multi-fiduciary' theories of the firm have been advanced as ways of ... empowering senior managers and directors sometimes to subordinate shareholder interests to those of employees, communities, or other groups affected by corporate activities.").

${ }^{16}$ See id.

17 See, e.g., Mitchell, Theoretical and Practical Framework, supra note 7, at 579-80 (discussing 'a 'constituency statute,' which authorizes ... corporate boards of directors to consider the interests of constituencies other than stockholders in making corporate decisions" (footnotes omitted)).

${ }^{18}$ See, e.g., Millon, supra note 1 , at 225 ("[D]irectors' duty statutes authorize management to consider the interests of various nonshareholder constituencies ... in making business decisions." (footnote omitted)).

${ }^{19}$ See, e.g., McDaniel, supra note 8, at 121-22 (arguing in favor of statutes that permit directors to consider nonshareholder interests); Millon, supra note 1, at 225 (describing statutes that permit directors to consider nonshareholder interests); David Millon, Theories of the Corporation, 1990 DUKE L.J. 201, 203-04 (same); Mitchell, Theoretical and Practical Framework, supra note 7, at 579-80 (same); Marleen A. O'Connor, Restructuring the Corporation's Nexus of Contracts: Recognizing a Fiduciary Duty to Protect Displaced Workers, 69 N.C. L. REV. 1189, 1229-30 (1991) (same); Katherine Van Wezel Stone, Employees as Stakeholders Under State Nonshareholder Constituency Statutes, 21 STETSON L. REV. 45, 45-47 (1991) (same); Steven M.H. Wallman, The Proper Interpretation of Comporate Constituency Statutes and Formulation of Director Duties, 21 STETSON L. REv. 163, 165 (1991) (describing constituency statutes as imposing a fiduciary duty on 
statutes. ${ }^{20}$ These statutes, which in various forms have been adopted by nearly thirty states, ${ }^{21}$ permit (or, in one case, require ${ }^{22}$ ) the board to consider workers, creditors, suppliers, consumers, and local communities in making decisions about corporate policy and strategy. Other advocates of a multifiduciary approach take a similar position without grounding their analyses on these statutes. ${ }^{23}$ These scholars would reconceptualize the board of directors as mediator among the various interests of nonshareholders and shareholders, in place of the standard conception of the board as agent for the shareholders.

By encouraging the board to consider nonshareholder interests when those interests conflict with the interests of shareholders, the multifiduciary model obviously would impose burdens on shareholders that do not exist under the current shareholder primacy regime. The conceptual basis for this change is the idea of the corporation as a community. The point is to propose an alternative to the contractarian notion of the corporation as, in effect, a marketplace that serves as a venue for atomistic individuals seeking to further their own interests through bargaining and exchange. The normative payoff of the corporation-as-community model is the suggestion that the web of

directors to act in the corporation's best interests but "not requir[ing directors] to consider shareholder interests or any other constituency's interests as dominant or controlling").

${ }^{20}$ See, e.g., Millon, supra note 1 (discussing directors' duty statutes and proposing an interpretive strategy); Mitchell, Theoretical and Practical Framework, supra note 7 (same).

${ }^{21}$ These include Arizona, Connecticut, Florida, Geórgia, Hawaii, Idaho, Illinois, Indiana, Iowa, Kentucky, Louisiana, Maine, Massachusetts, Minnesota, Mississippi, Missouri, Nebraska, New Jersey, New Mexico, New York, Ohio, Oregon, Pennsylvania, Rhode Island, South Dakota, Tennessee, Wisconsin, and Wyoming. For citations, see Millon, supra note 1, at 241 n.76. Delaware has not enacted one of these statutes.

${ }^{22}$ See CONN. GEN. STAT. ANN. § 33-756(d)(3) (West 1997) (“[A] director of a corporation ... shall consider, in determining what he reasonably believes to be in the best interests of the corporation,.... the interests of the corporation's employees, customers, creditors and suppliers ....").

${ }^{23}$ See, e.g., O'Connor, supra note 8, at 904 (noting that under the "neutral referee model" of corporate governance, "[d]irectors would owe fiduciary obligations to employees, including the duty to provide information and consult with them about strategic decisions that affect job security and working conditions"); see also Millon, supra note 19, at 203-04 ("Responding to widespread concerns about the harsh impact of hostile takeovers... [in the 1980s], state legislatures, courts, and commentators have focused on the notion of the corporation as aggregation, defined broadly to include not just shareholders and management but also other participants in the corporate enterprise."); Mitchell, Fairness Rights of Corporate Bondholders, supra note 7, at 1167 ("All but ignored by [views that corporations have few obligations to bondholders] is the powerful use of legal principles to express higher aspirations of community and cooperation such as those underlying fiduciary duty."). 
ongoing relationships constituting productive activities involves significant elements of interdependence and cooperation that cannot be captured fully by reference solely to a set of bilateral contracts. The content of these relationships gives rise to obligations existing independently of bargaining. ${ }^{24}$

\section{B. Progressive Contractarianism}

The second law reform strategy pursued by advocates of nonshareholder protection takes an approach different from the multifiduciary model. It focuses on lower-level workers among the corporation's various nonshareholder constituencies. Drawing on economic analyses of firms' internal labor markets, these scholars would require corporate management to honor implicit commitments to job security and deferred compensation. ${ }^{25}$ According to this model, the employment relationship involves compensation that is lower than the value of the worker's marginal product early in her career with the firm, with an implicit promise to pay more than its value later in her career. ${ }^{26}$ This pattern, which assumes job security and long-term

${ }^{24}$ As one scholar has noted:

The image of the corporation as the fee simple owner of its own property is an image that has outlived its usefulness. A better paradigm would focus on the industrial relations between and among the thousands of persons who participate in the ongoing affairs of the business or who depend on its success.... The rights of these thousands of persons are only partly governed by contract. The business constitutes a network of ongoing relationships. The factory is a locus for this network.

Joseph William Singer, The Reliance Interest in Property, 40 STAN. L. REV. 611, 640-41 (1988). In two recent essays, Professors Bratton and Mitchell discuss the importance of trust in production relationships. See Bratton, supra note 8; Mitchell, Trust. Contract. Process., supra note 7. Although these authors do not deal directly with the multifiduciary model in these essays, their focus on noncontractual aspects of relationships between contracting parties underscores the idea that there is more to production than contract alone.

${ }^{25}$ See O'Connor, supra note 19; O'Connor, supra note 8; Stone, supra note 19; Katherine Van Wezel Stone, Policing Employment Contracts Within the Nexus-of-Contracts Firm, 43 U. TORONTO L.J. 353 (1993).

${ }^{26} \mathrm{See}$ RONALD G. EHRENBERG \& ROBERT S. SMITH, MODERN LABOR ECONOMICS $398-$ 402,399 (6th ed. 1997) ("One feasible compensation-sequencing scheme would pay workers less than their marginal product early in their careers and more than their marginal product later on."); James N. Brown, Why Do Wages Increase with Tenure? Onthe-Job Training and Life-Cycle Wage Growth Observed Within Firms, 79 AM. ECON. REV. 971, 971 (1989) (arguing that the "human capital" model "explains the concave pattern of life-cycle earnings and wages as reflecting a similar pattern in life-cycle productivity, deriving from optimal investments that diminish gradually over the life cycle"); Robert Hutchens, Delayed Payment Contracts and a Firm's Propensity to Hire Older Workers, 4J. LAB. 
employment, encourages hard work to avoid discharge prior to payment of deferred compensation. It also encourages workers to make upfront investments in firm-specific human capital that they would be reluctant to make if discharge were a significant risk. The employer's commitments typically are not stated expressly and therefore are not enforceable under existing legal doctrine. ${ }^{27}$ Although reputational considerations may counsel against doing so, managers seeking to maximize corporate profits have a natural incentive to renege on these promises of job security and deferred compensation by discharging workers who have been with the company for a number of years. ${ }^{28}$ By making these commitments legally enforceable, corporate law could strengthen the currently precarious position of workers.

Law reform proposals based on implicit labor contracts do not rely on the creation of mandatory contract terms imposed by law upon the parties. Rather, they seek enforcement of implicit promises of job security grounded in a context of induced reliance. ${ }^{29}$ This approach to corporate law reform resonates with the communitarian regard for the costs of shareholder wealth maximization as they may affect workers. However, rather than attempting to redefine existing legal relationships, scholars relying on implicit labor contract theory look to the actual bargain as the basis for worker protection, seeking to identify the implicit understandings that rational employers and workers build into the employment contract. ${ }^{30}$ Because its normative

ECON. 439, 440-41 (1986) ("[E]mployers and employees may enter into implicit contracts whereby workers are underpaid at the beginning of the contract and overpaid at the end."); Edward P. Lazear, Agency, Eamings Profiles, Productivity, and Hours Restrictions, 71 AM. ECON. REv. 606, 606 (1981) ("[I]t is optimal to ... pay workers less than the value of marginal products ... when they are young and more than the value of marginal products when they are old."); James M. Malcomson, Work Incentives, Hierarchy, and Internal Labor Markets, 92 J. POL. ECON. 486, 488 (1984) ("Wage rates rise more with seniority and experience than productivity does.").

${ }^{27}$ See Stone, supra note 25, at 371-73 (noting that, under current legal rules in the United States, managers have the power to breach implicit contracts).

${ }_{23}$ See Note, Employer Opportunism and the Need for a Just Cause Standard, 103 HARV. L. REV. 510, 523-25, 524 (1989) (noting that "opportunistic discharges will occur on a regular basis . . . if job security provisions are costly to the firm").

${ }_{29} \mathrm{See}$ O'Connor, supra note 19, at 1203-07 (discussing various aspects of implicit labor contracts); Stone, supra note 25, at 366 ("Workers' investments in firm-specific capital and deferred compensation are made not on the basis of some explicit contractual arrangement, but rather take the form of an implicit contract.").

${ }^{30} \mathrm{See}$ O'Connor, supra note 19 , at 1239; Stone, supra note 25 , at $366-69$. 
foundation rests on bargain, this law reform strategy may be termed "progressive contractarianism."

\section{Critique}

\section{The Multifiduciary Model}

From the contractarian perspective, a board of directors empowered to rearrange contractually specified rights and duties interferes with efficiency and freedom of contract, which in turn rest on secure property rights. According to this view, the idea that a corporation's duty to its bondholders or workers extends beyond express contractual commitments amounts to an uncompensated transfer of wealth from the shareholders to the favored constituency. One might respond that the multifiduciary mandate (whether imposed legislatively or judicially) implies such a possibility in every shareholder's contract with the corporation, such that shareholders tacitly consent to its burden. This is the lesson of Justice Story's Dartmouth College concurrence $^{32}$ and of subsequent reservations of the power to amend that are included in every state corporation statute. ${ }^{33}$ The contractarian response would emphasize not only the unfairness of changing the terms of the deal to which current shareholders committed themselves, but also the uncertainty and consequent devaluation of property rights if the shareholders are subjected to the vagaries of the multifiduciary conception of the board's role.

Even if one does not accept the premises on which the contractarian critique of the multifiduciary model rests, the model is still vulnerable to questioning on other grounds. ${ }^{34} \mathrm{~A}$ mandate to consider

31 See Millon, Communitarianism, supra note 6 , at 16-19, 16 (noting that "[t]he common thread that runs through [progressive contractarians'] work is the argument that agreements-whether implicit or hypothetical-in actual bargaining relationships should provide the basis for legal intervention on behalf of aggrieved nonshareholders").

${ }^{32}$ See Trustees of Dartmouth College v. Woodward, 17 U.S. 250, 337, 4 Wheat. 518, 712 (1819) (Story, J., concurring) ("[A]ny act of a legislature which takes away any powers or franchises vested by its charter in a private corporation, or its corporate officers, or which restrains or controls the legitimate exercise of them ... is a violation of the obligations of that charter. If the legislature mean to claim such an authority, it must be reserved in the grant.").

${ }^{\text {ss }}$ See, e.g., MODEL BUS. CORP. ACT $\$ 1.02$ (1984) (reserving to state legislature the power to amend the act).

${ }^{94}$ For elaboration of these points, see Millon, Communitarianism, supra note 6, at $13-16$. 
nonshareholder as well as shareholder interests offers no guidance about how management is supposed to make tradeoff determinations in cases of conflict. ${ }^{35}$ Furthermore, assigning to management responsibility for the well-being of various nonshareholder constituencies replicates-and probably exacerbates-the accountability or agency cost difficulties already borne by shareholders. Finally, some might prefer a structure of governance that develops new market or political processes through which nonshareholders might better protect their own interests rather than having to rely on the paternalism of corporate management.

\section{Progressive Contractarianism}

The freedom-of-contract critique leveled against the multifiduciary strategy misses the mark when applied to progressive contractarianism. Progressive contractarians aim merely to remedy the opportunistic breaches of undertakings freely entered into by employers. This approach can, however, be questioned on other grounds. ${ }^{36}$ For one thing, the economists' "life-cycle earnings" model describes in a general way the relationship among a worker's actual wage, her opportunity wage, and the value of her marginal product, but the model is not intended to provide an actual measure for the discounted present value of an employer's commitment to job security in a particular case. ${ }^{37}$ Even if one accepts the theoretical soundness of implicit labor contract theory, it is largely indeterminate as a valuation measure in actual cases.

More fundamentally, the progressive contractarian argument accords normative significance to actual bargaining relationships. Like the express terms of the contract, the unstated, implicit undertakings are the products of actual bargaining. As such, market forces and workers' limited bargaining capabilities sharply restrict the range of possibilities. Although it may be in management's interest to induce workers to put forth high effort and to make firm-specific investments

${ }^{\text {ss }}$ Even proposals that attempt to put some flesh on the bare bones of the statutory structure rely on vague conceptions like "long-term strategies" and "legitimate nonshareholder expectations." See Millon, supra note 1, at 265-69 (discussing directors' duty statutes and offering interpretive principles).

${ }_{35}$ For a critique of progressive contractarianism, see Millon, Communitarianism, supra note 6 , at $19-22$.

${ }^{37}$ For example, Stone provides a graph that clearly expresses the relationship among these variables, but the graph does not purport to assign actual values to them. See Stone, supra note 25, at 365. 
in human capital, management can still preclude legal enforcement of worker expectations by expressly disclaiming them. ${ }^{38}$ Workers will be able to overcome such disclaimers only if they can afford the costs of legal protection. If they cannot afford to pay for job security (presumably in the form of a lower wage), they will be unable to obtain it. The progressive contractarian position is rhetorically forceful because it relies on bargaining as the basis for worker protection. It is, however, conceptually constricted by the bargaining limitations that workers inevitably confront, which impose a ceiling on the gains that workers can hope realistically to realize. ${ }^{39}$

ss See William H. Simon, What Difference Does It Make Whether Corporate Managers Have Public Responsibilities?, 50 WASH. \& LEE L. REV. 1697, 1701 (1993) (“[U]nder a reliance approach, managers can satisfy their responsibilities simply by discouraging reliance. For example, in the employment context, consistent disclaimers of any intention to provide job and compensation security should do the trick.").

${ }^{39}$ A further criticism of communitarian law reform proposals-both in their multifiduciary and progressive contractarian manifestations-might focus on the role of the state in their implementation and enforcement. See Stephen M. Bainbridge, Community and Statism: A Conservative Contractarian Critique of Progressive Comporate Law Scholarship, 82 CORNELl L. REV. 856, 885-90 (1997) (reviewing PROGRESSIVE CORPORATE LAW, supra note 6) (criticizing communitarians' asserted reliance on state power in their models). Professor Bainbridge favors a minimalist state, see id. at 890 . 91 , in contrast to what he calls the "nanny state," id. at 891 . In this regard, he asserts that the state's role should be "limited to that of a facilitator of private gain-seeking through provision of default rules." Id. at 890 .

One problem with Bainbridge's normative vision is its incoherence. His commitment to markets turns out to be qualified. In addition to facilitation of "private gainseeking," Bainbridge also believes that the state should promote "mediating institutions," id. at 892 , by which he means "churches, schools, and social clubs," id. at 884 . Such institutions are important, he says, for the inculcation of values like "virtue, trust, responsibility, and the like." Id. Like most advocates for social agendas, Bainbridge thus ends up endorsing an activist role for the state in the implementation of a substantive vision of a good society. He also has little to say about how the state should promote the institutions he favors, but the thrust of his remarks seems to be that private exchange alone will not suffice. See id. at 895 (suggesting that the state should create "a public square where the virtuous can act honorably").

Bainbridge's fundamental quarrel is with the notion that law might be used in efforts to ameliorate social problems. He cites a deep distrust of political reform (because of sinful human nature), see id. at $886-87 \&$ n.150, but otherwise has nothing to say about why the status quo-this status quo, including existing distributions of wealth and power-deserves to be perpetuated. If Bainbridge's form of argument had been accepted a thousand years ago, some of the institutions that he embracesespecially market-based capitalism-never would have emerged.

For a critical, but more thoughtful, exploration of the political theoretical implications of corporate law communitarianism, and the question of the role of the state in particular, see Cox, supra note 5, at 505-13. For example, Cox notes that liberation of managers from the state-imposed shareholder primacy norm might be construed as relaxation of a restrictive legal rule and therefore could be thought of as antistatist. See id. at 520-22, 521 (stating that "[i]f managers are to have full discretion, they 


\section{Law Reform and Default Rules}

Even if one accepts that the social costs of shareholder wealth maximization should be reduced through law reform, the criticisms of both the multifiduciary and progressive contractarian approaches to corporate law reform, outlined above, suggest the need for new law reform strategies. In what follows, I take my cue initially from the concern that the multifiduciary model of the board's duties is simply too vague and indeterminate a basis on which to ground prospects for meaningful law reform. This proposition seems particularly forceful in comparison with corporate law's traditional reliance on express contractual terms for the definition of management's responsibilities to nonshareholders. Contract also has the virtue of having a basis in mutual consent. However, reliance on contract is subject to the limitations on bargaining outcomes that are inherent in the existing distribution of wealth. Accordingly, this subpart proposes a law reform strategy that avoids or mitigates each of these shortcomings.

Whether the proposal can properly be termed "communitarian" will be open to question. However, its underlying impulse is twofold: a concern for the vulnerability of nonshareholders to the costs of shareholder wealth maximization, and a willingness to consider appropriate changes in the law. In this respect, the proposal resonates with the work of corporate law communitarians. Before turning to the proposal itself, this subpart begins by exploring the fundamental deficiency with the mainstream contractarian approach to corporate law.

\section{Bargaining Capability}

Contractarians have argued that nonshareholders have the technological capability to protect themselves from the costs of shareholder wealth maximization through bargaining and contract. If workers are worried about plant closings, they can bargain and pay for job security. Bondholders can seek protective covenants to cover risks not dealt with in standard bond indentures. ${ }^{40}$ For at least some nonshareholders, however, the feasibility assertion is debatable. Nonshareholders may lack access to information about future risks,

[would be] free to contract with providers of capital to abstain from commitment to Communitarian norms").

${ }^{10}$ See, e.g., sources cited supra note 11. 
and the costs of obtaining such information and then negotiating and drafting appropriate contract terms may exceed the benefits.

In addition, even if contractual self-protection is technologically feasible, obtaining protection depends on more than technological feasibility. The existing distribution of wealth imposes significant limitations on bargaining outcomes. Assume, for example, that a worker can obtain employment at a particular wage. In addition to the wage specification, the employment contract will also include a package of terms and conditions governing the employment relationship. These terms may be written or may be unwritten but understood by the parties as consistent with the established course of dealing in that particular labor market. Alternatively, they may be supplied by law in the form of default rules that apply in the absence of agreement, regardless of whether anyone actually has given them any thought. The standard package typically includes a term providing that employment is on an at-will basis. According to traditional common law doctrine, this means that the employer has the right to discharge a worker for any or no reason. ${ }^{41}$ If, instead, the worker prefers a term providing for security against discharge, the worker would have to persuade the employer to agree to that term and the worker would have to pay for that benefit. Payment would be necessary because the term imposes a cost on the employer that it otherwise would not have to bear. Presumably the worker would pay for job security by accepting a lower wage. ${ }^{42}$

The possibility of self-protection through contract thus turns on whether workers can afford to pay for it. Virtually everyone has limited resources and must make choices subject to constraints, such as the need for basic necessities of food, shelter, and clothing. Only after these basic needs are satisfied can the possibility of purchasing other goods be entertained. Trading cash income for protection

11 Most states now recognize a "public policy" exception to the employer's right to discharge. See MARK A. ROTHSTEIN ET AL., EMPLOYMENT LAW 542-53 (1994) ("Every state except Alabama, Florida, Georgia, Louisiana, New York, and Rhode Island, recognizes the public policy exception to the employment at will rule in one form or another."); id. at 54.3 ("Many... public policy cases are referred to as 'retaliatory discharge' cases, because the discharge is in retaliation for actions of an employee pursuant to public policy[, categorized as] (1) refusing to perform unlawful acts, (2) reporting illegal activity (whistleblowing), (3) exercising rights under state law, and (4) performing a civic duty."). Montana has enacted a wrongful-discharge statute requiring employers to show just cause for discharge. See MONT. CODE ANN. $\S \S 39-2-901$ to -915 (1997).

${ }^{42}$ An alternative would be for the worker to accept revisions of some other terms in the contract that would reduce the employer's cost. 
against discharge is especially difficult for those who are relatively poor because they have less discretion with respect to spending. As a practical matter, such workers might value job security highly, but might be unable to pay for it without having to make unacceptable sacrifices in other areas of their lives. In this sense, they lack the resources and, therefore, the capability to bargain and pay for protection. Self-protection might be technologically feasible but practically impossible. ${ }^{43}$

Although it is often said that workers are at a bargaining disadvantage in relation to employers, I do not refer to "unequal bargaining power" as a justification for the law reform proposal advanced here. As a basis for criticism of bargaining outcomes, the phrase possesses a variety of meanings. Differences in bargaining skill can affect the division of gains from trade. The concept of unequal bargaining power may also mean that outcomes are a function of one party's greater dependency on the other, such that the dependent party lacks bargaining leverage. ${ }^{44}$ Yet another use of the term is to refer to the ability of contracting parties to impose costs on each other as a mechanism for obtaining concessions. ${ }^{45}$ Differences in levels of risk aversion and fear of the consequences of failure to reach an agreement may also place one party at a bargaining disadvantage. ${ }^{46}$

While some or all of these notions of unequal bargaining power may be relevant to employment contracting, my emphasis is on a more fundamental feature of contemporary American life. In a social system that relies on bargaining and contracts, disparities in wealth and other advantages limit the ability of many people to obtain basic goods. As the gap between the rich and the poor grows wider, a model of social relations that relies excessively on private ordering to ensure individual well-being becomes increasingly difficult to justify. At some level, this concern about limited bargaining capability seems to unite the various communitarian objections to the corporate law contractarians' normative position.

${ }^{49}$ Obviously this argument works better for some nonshareholder constituencies, such as lower-level workers, than for others, such as large institutional bondholders.

14 See SAMUEl B. Bacharach \& EDWARd J. LaWler, Bargaining 79 (1981).

45 See BRUCE E. KAUFMAN, THE ECONOMICS OF LABOR MARKETS 560-62 (4th ed. 1994) (discussing bargaining power in the context of collective bargaining).

${ }^{45}$ See Melvin W. Reder, On Labor's Bargaining Disadvantage, in LABOR ECONOMICS AND INDUSTRIAL RELATIONS 237, 241-43 (Clark Kerr \& Paul D. Staudohar eds., 1994). 


\section{A Default-Rule Approach}

Concerns about limited bargaining capability do not necessarily imply a wholesale rejection of private ordering. The law reform approach considered in this Article would accept the priority of bargain as the basis for corporate relationships. In this respect, the proposal is contractarian. However, it would seek to improve the outcomes that nonshareholders can attain under current legal doctrine and, in the light of existing bargaining constraints, by changing existing contractual default rules that appear to privilege shareholders over nonshareholders. Part II of this Article considers whether such changes actually might be beneficial. Before turning to that question, however, it is necessary to discuss briefly default rules more generally.

As the various participants in corporate activities define the terms of their relationships with one another, they often will reach express agreements on various matters. Contractual silence can also serve this function because, in the absence of express agreement, an array of default rules will supply contract terms. Some of these rules are part of corporate law, such as the rule that provides for limited liability unless protection is waived. ${ }^{47}$ Others are not found in corporation statutes. For example, the common law at-will doctrine governs employment relations in the absence of express agreement to the contrary. ${ }^{48}$ Similarly, courts have held that corporate management enjoys the presumption of freedom to shut down a plant ${ }^{49}$ or incur additional $\mathrm{debt}^{50}$ despite harmful effects on local communities or existing creditors.

${ }^{47}$ See, e.g., MODEL BUS. CORP. ACT $\$ 6.22$ (b) (1984) ("Unless otherwise provided in the articles of incorporation, a shareholder of a corporation is not personally liable for the acts or debts of the corporation ....").

${ }^{48}$ ROTHSTEIN ET AL., supra note 41 , at 78 (stating that the presumptively at-will nature of employment contracts may be altered by agreeing that employment will only be terminated for "cause"); see also id. at 9-11 (discussing the common-law development of the employment-at-will doctrine).

${ }^{49}$ See Ypsilanti v. General Motors Corp., 506 N.W.2d 556, 561 (Mich. Ct. App. 1993) (stating that General Motors was not estopped from closing its plant even when it had accepted tax abatement from the city and had given hopeful proclamations of its long-term commitment, because it did not promise explicitly to remain open).

${ }^{50}$ See Metropolitan Life Ins. Co. v. RJR Nabisco, Inc., 716 F. Supp. 1504, 1508 (S.D.N.Y. 1989) ("There being no express covenant between the parties that would restrict the incurrence of new debt, and no perceived direction to that end from covenants that are express, this Court will not imply a covenant to prevent the recent [leveraged buy-out] ...."). 
The specification of rights and duties included in a default rule is not immutable because, by definition, the parties are free to contract around the rule. In this respect, default rules differ from mandatory ones. Default rules typically do, however, embody a bias: Shareholders enjoy limited liability, unless otherwise agreed, and employers can discharge workers at will, unless otherwise agreed. Default rules such as these presumptively favor one party over its counterpart, because they place the burden on the disfavored party to bargain out of the default term if that term is undesirable. This notion of presumption or burden gives rise to what I refer to as "default-rule bias." In reality, most default rules affecting the relationship of nonshareholders to the corporation are biased in favor of shareholders and their agent corporate management. $^{51}$

These biases are not themselves the product of contract. A default term cannot become part of a contract unless the parties enter into a contractual relationship with each other. However, the content of a default rule-including its bias-is the product of prior state action. A statute or a judicial decision establishes the default rule independent of private bargaining. In this sense, default rules and their biases are precontractual. ${ }^{52}$

The remainder of this Article will consider whether nonshareholders might gain from reversing current default rules such that the new rules will be biased in favor of nonshareholders against shareholders. The intuition I wish to pursue is the possibility that the beneficiaries of default rules receive an advantage in relation to the parties with whom they contract. This is not a novel approach to law reform. For example, consumer warranties that apply unless expressly disclaimed ${ }^{53}$ are assumed to make buyers better off than they would be if the default rule were caveat emptor. Another example is the landlord's implied warranty of habitability, which, under the Second Restatement of Property, is waivable absent unconscionability or public-policy concerns. ${ }^{54}$

It is not at all obvious, however, that default rules benefit the parties whom they appear to favor, or that choices between default rules have any effect on bargaining outcomes. It is at least possible that

51 See supra notes 47-50.

52 See Millon, Communitarianism, supra note 6, at 25 (" $[\mathrm{T}]$ he bias of [a default rule] ... is not a product of agreement. A legal rule has already determined that question, and it has done so precontractually.").

${ }^{53}$ See, e.g., Henningsen v. Bloomfield Motors, 161 A.2d 69, 90 (N.J. 1960).

${ }^{34}$ See RESTATEMENT (SECOND) OF PROPERTY: LANDLORD AND TENANT $\$ 5.6$ (1977). 
contract terms are fully priced by the parties such that the choice between alternative terms (for example, limited liability versus personal liability or at-will versus job security) does not affect the parties' wealth. If so, assuming full information and leaving aside possible transaction costs, changing default rules to their opposites should make no distributive or allocative difference. As discussed below, this is the orthodox law-and-economics view. ${ }^{55}$ Part II questions the validity of that view.

\section{The At-Will Default Rule}

In exploring a default-rule approach to law reform, this Article focuses on a particular example, the employment-at-will default rule. Despite recent inroads, the prevailing employment practice in this country continues to be employment at will. ${ }^{56}$ That is, nonunionized workers can be discharged by their employers at any time and for virtually any reason. ${ }^{57}$ For the employer to enjoy this freedom, an employment contract need not include an express provision so providing. As a default rule, the at-will contract term will be supplied by the law in the absence of an agreement to the contrary. ${ }^{58}$

An alternative to the at-will contract term would be a default rule guaranteeing job security. Express promises of job security are generally phrased in terms of a requirement that the employer discharge the worker only for "just cause." 59 This generally implies security of tenure except in cases of worker malfeasance or nonfeasance. ${ }^{60}$ In addition, a just-cause job-security term typically allows discharge in the event of genuine economic necessity. ${ }^{61}$ Although a job-security

${ }^{55}$ See infra text accompanying note 72.

${ }^{56}$ See Clyde W. Summers, Worker Dislocation: Who Bears the Burden? A Comparative Study of Social Values in Five Countries, 70 NOTRE DAME L. REV. 1033, 1035-36 (1995) ("All employment is at will unless a specific contractual provision provides to the contrary.").

${ }^{57}$ In recent years, state courts have created a public-policy exception to the at-will doctrine, such as discharge for refusal to perform unlawful acts or for reporting unlawful activities. See supra note 41 . Unionized workers may enjoy job-security protections, but only a tiny fraction of the workforce in this country is unionized. The percentage of the workforce that is unionized seems to decline each time the statistics are updated. As of 1996, union members accounted for $14.5 \%$ of wage and salary employment, down from $14.9 \%$ in 1995. See Union Members in 1996, NEws (Bureau of Labor Statistics, U.S. Dep't of Labor, Washington, D.C.), Jan. 31, 1997, at 1.

${ }^{38}$ See ROTHSTEIN ET AL., supra note 41 , at 78.

${ }^{59}$ For a discussion of just-cause limitations, see $i d$. at $540-42$.

${ }^{60}$ See id. at 541.

${ }^{61}$ See id. 
default rule could be defined in various ways, it most conveniently might be taken to incorporate current understandings of these justcause limitations. Accordingly, if job security rather than employment at will were the default rule, a worker would enjoy these protections absent an actual agreement to the contrary. ${ }^{62}$

I propose to change the current employment-at-will default rule to a job-security default rule. In keeping with the bargaining capability idea previously discussed, ${ }^{63} \mathrm{I}$ would limit that change to hourlywage as opposed to salaried employees. The case for improving the latter group's bargaining outcomes is, generally speaking, not as strong as it is for less wealthy members of the workforce.

In advancing this proposal, my objective is not for job security necessarily to replace employment at will as the usual contracting practice. ${ }^{64}$ Rather, in accordance with the ameliorative agenda laid

${ }^{62}$ Other default rules could be modified in a similar manner. For example, current default rules could be replaced by presumptions specifying unlimited shareholder liability or imposing on management an obligation of good faith and fair dealing toward creditors.

${ }^{63}$ See supra Part I.D.1.

${ }^{64}$ If one were serious about ensuring job security on a widespread basis, one could advocate a mandatory rule requiring job security in all employment contracts. Whether workers would necessarily be better off depends on how much they would have to pay for this benefit in the form of lower wages. See infra note 90 . In light of the possibility that a mandatory job-security term could be harmful to workers, it would seem that such a change in the law might be a bad idea. However, even if a mandatory job-security term would make workers worse off, one could still reject workers' valuation of job security. A societal judgment that workers are better off with job security, despite the reduction in wages, could displace individual judgments. Lawmakers sometimes engage in paternalistic mandates of this sort when they are convinced that the choice in question is a bad one, such as when they prohibit the consumption of various substances. Such societal judgments may be based on concerns about the external effects of the behavior in question, or they may reflect doubts about the voluntariness of certain choices. Alternatively, some choices may simply be deemed too self-destructive or degrading to the individual to be worthy of respect. See DON HERZOG, HAPPY SLAVES 237 (1989) ("We value choice, ... but some options are so self-destructive that we won't allow people to choose them, even if they act voluntarily."). The illegality of a contract selling oneself into slavery is an obvious example. One might say that, from an objective standpoint, such choices are substantively irrational.

The choice we are considering here-a preference for at-will employment and a higher wage-does not seem to warrant societal prohibition due to substantive irrationality or doubts about voluntariness. For many workers, a preference for current income over job security may be quite rational. Some older workers, for example, may no longer be as concerned about discharge as their younger colleagues because they are nearing retirement age and have the financial capability to retire sooner if they must. For these workers, what amounts to an employer-provided insurance policy (priced with younger workers in mind) would not be worth the cost. Even younger 
out above, my focus is on the question of whether workers might end up wealthier under a new default rule. Because the job-security term would be a default rule rather than a mandatory one, workers and employers would be free to contract for an at-will provision instead. If workers continue to work on an at-will basis for the most part, but earn higher wages, I would count that as success. Conversely, if, as a result of changing the default rule, job security were to replace at-will employment, but the value to workers of job security plus wages (and other noncash benefits) was lower than the value of at-will employment combined with current compensation packages, workers would be worse off and the contemplated legal change would be a mistake. ${ }^{65}$

Replacing the at-will default rule with a job-security default rule may appear questionable for various reasons. At the very least, a jobsecurity regime appears to run counter to current economic developments in this country that are assumed to be driven by irresistible global competitive forces. ${ }^{66}$ In response, I reiterate that I am considering job security only as a default rule. Workers and employers for

workers may differ among one other in their assessments of the risk of discharge. It will often be hard to say that such assessments should be disrespected. And, even where assessments of risks are similar, workers will differ in their attitudes toward risk. A young worker with marketable skills who lacks family responsibilities or roots in a community may well be willing to accept the risk of discharge in exchange for higher cash compensation. Other workers for whom stability is more important will view the matter differently.

One might still suggest that a mandatory job-security term is necessary if one is concerned that some workers, by preferring at-will status and higher pay, impose costs on others who have not agreed to bear them. Perhaps, the argument might go, workers should not be allowed to make this choice when its consequences will fall on family members who are dependent on their employment. Other social costs would include increased burdens on welfare agencies and creditors. Even if this argument could apply to some workers, it may not be strong enough to justify an across-theboard job-security mandate. For many workers, young and single, or older and financially secure, a preference for at-will status and higher pay does not create negative externalities. Given uncertainty about the magnitude of the social costs associated with at-ivill employment, a law reformer probably should hesitate to impose a mandatory job-security term for this reason alone. Furthermore, a mandatory job-security term could itself generate significant social costs, such as higher labor costs and lower levels of employment, that would otherwise not be present and that would outweigh any benefits. Such concerns are speculative, but, when added to the uncertainty about the social costs of at-will employment, the result may well be a heightened reluctance to require job security.

${ }_{65}$ This would happen if transaction costs were greater than the wage differential.

${ }^{66}$ Professor Gordon describes a "New Economic Order" characterized by enhanced flexibility in firms' ability to make workforce adjustments in response to market pressures and opportunities, as well as by liberalization in international trade and capital markets. See Jeffrey N. Gordon, Employees, Pensions, and the New Economic Order, 97 COLUM. L. REV. 1519 (1997). 
whom job security is undesirable would remain free to opt out of the default and return to an at-will contract term. Barring excessive transaction costs, one would expect this to occur if both parties would be better off by doing so. If at-will employment is truly more efficient than job security, changing the default rule to job security would not necessarily result in widespread adoption of a new contract term.

Seen in this light, my proposal may seem more modest than it initially appears. Depending on the magnitude of the distributive effects discussed below, it may not do enough to address the bargaining capability concern that I have identified as the motivation for what follows. ${ }^{67}$ In particular, although my proposal may improve bargaining outcomes for workers, it will not necessarily provide workers with the resources needed to obtain job security. If that were the case, further law reform might be in order. Meanwhile, though, workers would still be better off, even if not as well off as they may deserve to be.

It should be clear that the point of this exercise is to consider the effects of alternative default rules on wealth distribution. In recent years, law-and-economics scholars have produced an impressive body of work on the efficiency implications of default-rule selection. ${ }^{6}$ Efficiency enhancement, however, is not the focus of this Article. ${ }^{69}$ Although workers might benefit from a more efficient default rule, I am interested in the possibility of benefits unconnected with greater efficiency.

\section{DeFaUlT RuleS AND DISTRIBUTION}

At first glance, it might seem easy to assume that switching the default rule from employment at will to job security would benefit workers. Other things remaining equal, workers presumably would prefer job security to the risk of discharge at the will of the employer. If

67 See supra Part I.D.1.

${ }^{63}$ See, e.g., Ian Ayres \& Robert Gertner, Strategic Contractual Inefficiency and the Optimal Choice of Legal Rules, 101 YALE L.J. 729 (1992) (showing how default rules can affect strategic bargaining); Jason Scott Johnston, Strategic Bargaining and the Economic Theory of Contract Default Rules, 100 YAIE L.J. 615 (1990) (explaining the implications of strategic bargaining for "penalty" default rules); Robert E. Scott, A Relational Theory of Default Rules for Commercial Contracts, 19 J. LEGAL STUD. 597 (1990) (developing criteria for the selection of optimal default rules).

${ }^{i 9}$ In Part III, I consider whether the prevalence of at-will employment indicates superior efficiency, but only in order to assess the argument for an at-will default rule based on the avoidance of the costs of contracting around an inferior default. See infra Part III.B.1. 
changing the default rule could bring about this state of affairs, surely this would be a change for the better. Of course, the problem with this view is that other things would not remain equal. Because workers and employers must reach agreements satisfactory to each party, employers cannot be forced to confer a benefit on workers if it is costly to do so. If an employment agreement contains a job-security clause, workers will presumably have to pay for it in the form of lower wages. Such a reduction may be acceptable to workers because they gain the benefit of job security. However, if workers value job security less than its cost to employers, the parties presumably will bargain around the job-security default and attempt to reach agreement on an at-will basis instead. In short, whether workers would actually benefit from a job-security default rule is more complex than a naive assessment might suggest. Nevertheless, this way of thinking seems to be common. For example, in another context, the proliferation of new forms of organization for small businesses purports to confer limited liability on the owner-investors. ${ }^{70}$ Contract creditors, however, can be expected to take this factor into account in pricing credit extensions. They cannot be forced to accept limited liability without compensation for the increased risk of insolvency. ${ }^{71}$

An apparently more sophisticated view-associated with mainstream law and economics-would deny that changes in default rules have any efficiency or distributive effects at all. These theorists argue that, at least in the absence of transaction costs, contracting parties will reach efficient outcomes regardless of the legally specified default rule. $^{72}$ That is, contracting parties will settle on a particular wage, coupled with either an at-will or job-security term, as determined by their calculations of self-interest. Furthermore, according to this view, the choice of default rule will not have any distributive consequences, because the default rule, as a starting point for bargaining, will not determine the amount of each party's share of the gains from

${ }^{70}$ For an overview, see Allan W. Vestal, New and Revised American Laws for Unincorporated Firms Create Significant Traps for the Unwary, in 2 PERSPECTIVES ON COMPANY LAW 257 (Fiona Macmillan Patfield ed., 1997).

${ }^{71}$ Potential tort creditors are in a different situation because they are unable to bargain ex ante with potential injurers.

${ }_{72}$ See, e.g., R.H. Coase, The Problem of Social Cost, 3 J.L. \& ECON. 1, 15 (1960) ("It is always possible to modify by transactions on the market the initial legal delimitation of rights. And, of course, if such market transactions are costless, such a rearrangement of rights will always take place if it would lead to an increase in the value of production."). Note, however, that Coase was writing about property entitlements, not contractual default rules. For a discussion of this distinction, see infra Part II.A.2. 
trade. Each party's gains will depend instead on such factors as the parties' respective bargaining skills and leverage. Recent scholarship modifies this view, positing that, under certain circumstances, choices between alternative default rules may indeed affect efficiency. ${ }^{73} \mathrm{Al}$ though the question has received considerably less attention, such choices may also have significant distributive consequences. This Part considers that issue, but only after clarifying one way in which choices between alternative default rules do not influence distribution.

\section{A. Property Rules and Contract Rules}

\section{Distributive Effects of Legal Rules}

In his famous article The Problem of Social Cost, Professor Coase shows that, under certain circumstances, the assignment of a legal entitlement to one party over another makes no difference to the allocation of resources. ${ }^{74}$ To illustrate this, Coase offers the example of a farmer and a cattle rancher occupying adjacent properties. ${ }^{75}$ The rancher's cattle wander onto the farmer's land and damage her crops. As the size of the rancher's herd increases, the amount of crop damage increases as well. ${ }^{76}$ Coase contrasts two legal responses to this situation. The law may assign to the farmer an entitlement to compensation for damage (or an injunction to prevent the damage from occurring), or it may assign to the rancher an entitlement to inflict damage on the farmer's crops. ${ }^{77}$ Coase demonstrates that absent transaction costs, ${ }^{78}$ the parties will bargain to the most efficient outcome regardless of which party receives the entitlement. ${ }^{79}$

Even though the initial assignment of the legal entitlement to one party or the other makes no allocational difference in the absence of transaction costs, the choice of initial assignment has significant consequences for the distribution of wealth between the farmer and the rancher. ${ }^{80}$ If the cost to the farmer of the marginal steer is less

73 See sources cited supra note 68.

74 See Coase, supra note 72 , at 2.

${ }^{75}$ See id. at 2-3.

${ }^{76}$ See id. at 3.

7 See id. at 3-4.

${ }^{78}$ Coase acknowledges that an assumption of no transaction costs is "very unrealistic." Id. at 15.

${ }^{79}$ See id.

${ }^{80}$ Various commentators have made this point. See, e.g., JULES L. ColEMAN, MARKETS, MORALS AND THE LAW 71 (1988) ("The initial assignment of entitle- 
than its value to the rancher, the rancher will increase the size of her herd regardless of the legal rule. However, if the farmer enjoys the entitlement, she will be able to insist on compensation in some amount sufficient to pay for her damage but still allow the rancher a profit. If, instead, the law allows the rancher to damage the farmer's crops without paying compensation, the rancher claims the full value of the marginal steer, and the farmer is left to bear her loss without compensation. Even if both results are equally efficient, the farmer surely prefers one state of affairs to the other.

Likewise, if the farmer will sustain crop damage more costly than the value to the rancher of the additional steer, a rule entitling her to damages or an injunction will suffice to prevent the rancher from enlarging the herd, as the cost to the rancher of doing so would be greater than the benefit. However, if the rancher has the entitlement, the farmer will have to pay the rancher to refrain from enlarging the herd. ${ }^{81}$ Again, the allocational outcome is the same either way, but the farmer is not indifferent.

Whatever the relationship between the value of crops and the value of cattle, the party to whom the legal entitlement is assigned will fare better in relation to the other party than she would if the opposite legal regime were in effect. If the farmer's property rights include a right to money damages or an injunction, she will be able to insist on compensation for the crop damage caused by the rancher's cattle. However, should the farmer enjoy no such entitlement, she will either have to bear the loss, or, if it is cost-effective to do so, pay the rancher not to raise the additional steer. The same analysis can be applied to a variety of legal entitlements. A railroad company may

ments ... does affect the relative wealth of the competing parties simply because the assignment determines which party has to do the purchasing (or what economists misleadingly call bribing)."); A. MITCHELL POLINSKY, AN INTRODUCTION TO LAW AND ECONOMICS 12 (2d ed. 1989) ("[A]lthough the choice of the legal rule does not affect the attainment of the efficient solution when there are zero transaction costs, it does affect the distribution of income."); MARK SEIDENFELD, MICROECONOMIC PREDICATES TO LAW AND ECONOMICS 93 (1996) ("[E]ven in a world of zero transaction costs, although every legal rule will lead to the efficient outcome, different legal rules will have different [wealth-distribution] effects on the parties involved."); Harold Demsetz, Wealth Distribution and the Ownership of Rights, 1 J. LEGAL STUD. 223, $227-28$ (1972) (noting that the initial assignment of the legal entitlement "merely reclassifies costs from explicit to implicit for the parties to the interaction," and that "such a reclassification is merely a way of describing the resulting redistribution of wealth.").

${ }^{81}$ For the parties to reach an agreement, the amount of the payment will have to be greater than the value to the rancher of the steer but less than the cost to the farmer of the crop damage. 
or may not be liable for fires caused by sparks emitted from its trains onto adjoining land. ${ }^{82}$ Homeowners living next to a factory may or may not enjoy a right to clean air. ${ }^{83}$ A slaughterhouse may or may not be responsible to landowners downstream for discharging refuse into a river. ${ }^{84}$ Even though market prices ultimately will dictate investment decisions, the law has a direct effect on how much each party stands to gain or lose.

\section{Property Versus Contract}

Rules of the kind Coase analyzes may be termed "property entitlements" in order to contrast them with contract-based rights. The law can give the farmer a right to compensation for damages caused by a neighbor's cattle, or it can deny her a right to compensation, in effect giving the neighboring rancher freedom to inflict damage on the farmer's crops. In either event, the entitlement in question is a creation of positive law, existing prior to and independently of any contractual relationship between the parties. This is true of any number of property rules that define the relationship between an owner and those who infringe upon or are adversely affected by the owner's efforts to enjoy the property in question.

Contract-based rights are not creations of positive law. Rather, they arise out of bargains struck between parties to contractual relationships. Although property rules may give an owner rights to security of possession, if the owner seeks to sell the property, issues such as the sale price, timing of the transfer, warranty, and the like, must be determined contractually. Similarly, parties to an employment relationship define their respective rights and duties by means of a contract. Some terms may be supplied by law. Default rules specify terms that will apply in the absence of an agreement to the contrary. Mandatory rules may also supply terms around which the parties are not allowed to contract. In either case, however, such terms, and any

${ }^{82}$ See SEIDENFELD, supra note 80 , at $91-93$ (analyzing the consequences of giving the legal right to either the railroad (to set fires) or the landowner (to receive compensation for fire damage)).

${ }^{83}$ See POLINSKY, supra note 80, at 11-14 (discussing the distributive effect of the choice of legal rule).

84 See Herbert Hovenkamp, Technology, Politics, and Regulated Monopoly: An American Historical Perspective, 62 TEx. L. REV. 1263, 1298 (1984) (discussing how the Louisiana legislature's pro-slaughterhouse laws of the 1860 s permitted butchers located upstream from New Orleans to discharge their animal wastes into the Mississippi River, contaminating the city's drinking-water supply). 
others that the parties themselves choose, will confer rights or impose duties only by virtue of a contractual relationship that the parties voluntarily have undertaken.

To what extent do choices between alternative contractual default rules have distributive consequences similar to those produced by choices between rival property entitlements? Here is where one may be tempted to analogize contractual default rules to Coase's property entitlements. ${ }^{85}$ A rule that gives a farmer a right to an injunction or to money damages against a neighboring cattle rancher creates an asset that can be the subject of bargaining and exchange. If it is economical to do so, the cattle rancher will purchase this right from the farmer by paying for the right to raise a herd that damages the farmer's crops. The benefit to the rancher presumably exceeds the cost of paying off the farmer. This process is what Coase has in mind when he refers to the "rearrangement" of rights ${ }^{86}$ or to their transfer and recombination. ${ }^{87}$

The at-will employment rule (like other default rules) might be thought about in a similar manner. If the worker is willing to pay the price (in the form of lower wages), the employer will give up its right of at-will discharge in favor of some kind of job-security agreement. Presumably the worker will do this only if she values the job-security term more highly than the forgone wages, while the employer will agree only if it values the cost savings more highly than the burden of a job-security contract term. Again, the legal rule, being a default rule, is only a starting point for negotiations, the outcome of which will be determined by economic considerations.

Does the choice of a starting point have distributive implications similar to those that attend choices between rival property entitlements? Suppose, for example, that an employer values the cost savings of a large-scale layoff more highly than the workers value their jobs. If employment is at-will, the employer can discharge the workers in question and realize the attendant cost savings. If the workers enjoy some kind of right to job security, the employer should still be able to compensate the workers for their losses and come out ahead. The layoff happens either way. The difference is that in the former situation, the workers do not receive compensation, while in the latter

${ }^{85}$ See Millon, Communitarianism, supra note 6, at 27.

${ }^{86}$ Coase, supra note 72, at 15.

${ }^{87} \mathrm{See}$ id. at 8 ("It is necessary to know whether the damaging business is liable or not for damage caused since without the establishment of this initial delimitation of rights there can be no market transactions to transfer and recombine them."). 
situation, they do. Stated this way, the distributive picture looks like the one we saw in the case of the cattle rancher and the farmer: Workers are better off if the default rule is job security than if it is atwill. Superficially, at least, the bias that contractual default rules embody $^{88}$ seems analogous to the distributive advantage that one party or the other receives from a property entitlement.

Any appearance of similarity is in fact misleading. The crucial difference between the employment case and Coase's adjoining landowners example results from the fact that the employer and the worker are in a different kind of relationship than are the farmer and the rancher. The job-security contract term exists only if the parties directly affected by it have agreed to include it in the employment contract. If a worker is to enjoy job security, the employer must first agree. This means that the employer is in a position to make the worker pay for whatever benefit the job-security contract term offers to the worker, taking into account the increased cost that such a provision imposes on the employer. If job security involves costs that employment at will does not, presumably the employer will make the worker pay for it. ${ }^{89}$ This is the importance of the difference between contract-based rights and property entitlements, described by Professor Demsetz as the distinction between "exchange" and "nonexchange" situations. ${ }^{90}$

${ }^{8}$ As discussed above, see supra text accompanying note 52 , bias refers to the fact that the at-will default rule gives employers, for example, the right to discharge workers without cause; if workers desire job security, the burden is on them to bargain for it.

${ }^{89}$ It is possible that job security would generate benefits as well as costs. One line of recent economic research draws on an extensive social psychology literature to posit a connection between psychological well-being and productivity. One determinant of psychological health appears to be secure employment. See generally William Darity, Jr. \& Arthur H. Goldsmith, Social Psychology, Unemployment and Macroeconomics, J. ECON. PERSP., Winter 1996, 121, 122-30 (discussing the negative psychological effects of unemployment and relating them to lower productivity and other behavioral phenomena among the employed).

Soe Demsetz, supra note 80, at 224-28. The point of the distinction for Demsetz is that, generally speaking, changes in mandatory contract rules have no distributive impact. See Harold Demsetz, When Does the Rule of Liability Matter?, 1 J. LEGAL STUD. 13, 22 (1972) (" $[W]$ hen there is no restriction on contracting, a change in the rule of liability need not be accompanied by wealth redistribution."); see also Demsetz, supra note 80 , at 228 . To illustrate, Demsetz discusses the problem of liability for on-the-job accidents. See id. at 224-27. If employers are required by law to compensate workers for on-the-job injuries, the cost of doing so is a cost of employing labor, and employers must, consequently, pay a lower wage than they otherwise would. See id. at 225. Workers accept the lower wage because it is supplemented by what amounts to accident insurance, obviating the need either to purchase insurance or to self-insure. The 
A job-security contract term does impose costs on employers that are not present under an at-will regime. Most notably, if discharge is lawful only in cases of worker misconduct or inadequate effort, there is a substantive restriction on employers' freedom to make workforce adjustments in response to market considerations. Faced with new economic pressures, employers may find themselves stuck with workers whose marginal product is worth less than their marginal cost. If they must compensate these workers in order to discharge them, employers will want to take this cost into account in deciding how much they are willing to pay for labor generally.

Procedurally, the job-security term will place the burden of justification on employers who have discharged a worker. Even if the discharge is justifiable on grounds of malfeasance of some kind, a disgruntled worker may still bring a wrongful-discharge lawsuit. The

bargaining process incorporates the costs and benefits of the new contract-based right into the wage rate. See id. As Demsetz puts it: "It would seem that the distribution of wealth between workers and [employers] is unaffected by the legal position because of the offsetting alteration in explicit wages." Id.

In fact, Demsetz's result depends on an assumption that may be peculiar to the example he chooses. Accident compensation involves cash transfers from the employer to injured workers. The cost to the employer is precisely equal to the dollar value of the benefit paid to those workers who end up with a right to be compensated. Under such circumstances (but assuming no valuation differences based on wealth effects), both the labor supply and demand curves should shift by identical magnitude, and the invariance result is as Demsetz posits. See id.

Different results can obtain, however, if the value of the benefit to the workers is not equal to the cost to the employer. When might this be the case? Suppose that the law mandates a job-security contract term. Employers in a particular market determine that the added cost of job security requires that they reduce wages by $\$ 3$ per hour. Assume also that, all other things being equal, workers prefer job security over at-will employment. Because they prefer a job-security contract term over at-will status, they are willing to pay some amount for that benefit, perhaps in the form of reduced wages. Just how much they are willing to pay-how large a wage reduction they will accept-depends, of course, on how great a value they place on a job-security guarantee. The value could conceivably be precisely equal to the cost that the employer must bear, but there is no reason for why this has to be the case. The value that workers place on job security may be greater or less than the term's $\$ 3$ cost per hour to the employer. This is simply an instance of the fact that the value of a good to one person does not depend on how much it costs another to produce it. The invariance scenario is likely only in situations in which the cost to the employer equals the benefit to the workers. Although this may be the case with respect to benefits in the form of cash transfers, invariance in cases involving noncash benefits would appear to be unlikely, though not impossible.

Accordingly, if a mandatory job-security term were imposed, workers might be better or worse off (or there might be no change) depending on the relationship between the cost to the employer and the value of the benefit to the workers. For a careful discussion of this issue, see Richard Craswell, Passing on the Costs of Legal Rules: Efficiency and Distribution in Buyer-Seller Relationships, 43 STAN. L. REV. 361 (1991). 
cost of defending against such a claim can be substantial, and there is always at least some uncertainty as to the outcome. These considerations may encourage opportunistic litigation by creating settlement leverage unrelated to whether the grievance is grounded in employer bad faith or honest disagreement. ${ }^{91}$ In comparison to an at-will regime, the specter of higher litigation and settlement expenses increases the cost of using discharge as a mechanism for disciplining workers who fail to live up to employer expectations. ${ }^{92}$ Discharge is not a perfect disciplinary device under an at-will regime either, because detection is costly and opportunistic litigation is still possible. Nevertheless, shirking and other misconduct will be harder to punish and, therefore, more likely to occur under a job-security contract term than under an at-will term. This extra increment represents a cost peculiar to a job-security regime, and it is a cost that employers will seek to pass on to the work force.

Even if the job-security contract term allows for discharge in the event of economic necessity, there are costs involved in exercising that right, in addition to the costs involved in trying to discharge underperforming workers. The uncertainty that can surround the question of necessity may give rise to litigation. Success for the employer, if it comes, will likely be costly. That fact alone creates settlement leverage and may tend to encourage opportunistic litigation.

When a benefit like a job-security term involves costs that the employer must bear, the employer will not simply assume that cost without attempting to reflect it in a lower wage. Whether job security is a default rule, therefore, conceivably could make no difference. The job-security term may be a negotiated departure from an at-will default rule, or it may itself be the default. Either way, the parties to the employment contract will price the term in question, each taking into account the costs and benefits of employment under a job-security regime. Thus, although the farmer can insist on the full market value of her legally assigned property right, the worker will not get the full value to her of a job-security contract term, because that term will be part of the bargain between the worker and the employer only if both parties agree.

As Coase's analysis demonstrates, social choices about the assignment of property entitlements can have dramatic wealth effects, even

${ }^{91}$ See Richard A. Epstein, In Defense of the Contract at Will, 51 U. CHI. L. REV. 947, 970 (1984) (discussing the advantage of lower administrative costs associated with contract at will).

${ }^{92}$ For a discussion of the at-will rule as a disciplinary device, see id. at 965 . 
if such choices do not necessarily determine resource allocation..$^{93}$ In contrast, although contractual default rules may be biased in favor of one class of contracting parties or another, such rules do not determine the outcome of the bargaining process because the parties are free to substitute an alternative to the default rule. Moreover, the law's assignment of default-rule bias does not confer wealth on the rule's beneficiaries in the same manner that a property entitlement does, because the rule confers no rights at all in the absence of an actual bargain. The bargaining process ensures that the beneficiary of a contract term must pay for those gains one way or another, while the party burdened by a term cannot be forced to bear a greater share of such costs than she is willing to assume. Because the worker will have to pay for the job-security contract term whether that term is a default rule or a negotiated departure from an at-will default, the distributive consequences of choices between default rules creating contract-based rights are not as dramatic as those between alternative property entitlements. ${ }^{94}$ Whether there is any distributive significance is discussed in the next subpart.

\section{B. Default Rules and the Distribution of Gains}

If one default rule benefits both workers and employers more than its alternative, those seeking to improve the welfare of workers would favor such a rule. This might occur if a particular default rule increases efficiency in contracting outcomes. The flip side of this point is that default-rule choices can also interfere with efficiency. The default rule may express a contract term that is less desirable to the parties than its alternatives. In such cases, the parties will attempt to contract around the default to a superior alternative. Such efforts are likely to generate costs. Even if the parties succeed, these costs mean that the parties will end up less well off than they would have

${ }^{93}$ See supra text accompanying notes 80-81.

${ }^{94}$ If the efficiency and distributive effects are uncertain, one might be tempted to conclude that social choices about default rules are unimportant. Professor Black has suggested that, taken as a whole, the mandatory component of state corporate law is trivial. See Bernard S. Black, Is Corporate Law Trivial?: A Political and Economic Analysis, 84 Nw. U. L. REV. 542, 551-61 (1990) (arguing that mandatory rules mimic solutions that parties would reach through bargaining, are avoidable, are unimportant, or tend to be eliminated through an ongoing dynamic adjustment process). If corporate law's mandatory rules are trivial, Black's analysis would seem to imply that its structure of default rules must be as well, since these rules impose no restraints on the choices that participants in corporate activity may make about the terms on which they contract with each other. 
been had the more desirable term been the default rule. Under certain circumstances, transaction costs may exceed the benefits to be gained from avoidance of the default term. In such cases, the result will be a contract that includes the inferior term. In either situation, the contracting process yields less value than could have been realized had the opposite default rule been in effect.

Although the effect of default rules on efficiency is an important question, ${ }^{95}$ the remainder of this subpart focuses on the distribution of gains from trade and whether workers may be better off under one default rule rather than its alternative. This could be the case if a jobsecurity default rule results in employment contracts that include a job-security term but at a wage higher than workers can obtain when employment at will is the default rule. Alternatively, in bargaining from the job-security default to an at-will contract term, employers might pay a higher wage than they would have paid if the default rule had been employment at will. Under either scenario, workers would be better off under a job-security default.

In thinking about how choices between alternative default rules might enhance the wealth of workers, I wish to focus on a particular mechanism. First, I discuss the "endowment effect" and the related notion of "status quo bias." These terms describe how ownership of an entitlement can affect the value placed on it by its owner. Then I consider whether default rules might be subject to the endowment effect even though default rules, by themselves, do not create entitlements. ${ }^{96}$ Finally, I turn to the possibility that, if job security were the default rule, the endowment effect might interfere with the ability of workers and employers to reach agreements. ${ }^{97}$

\footnotetext{
${ }^{95}$ For a brief discussion of the efficiency implications of default-rule selection, see infra Part III.A.

${ }^{96}$ See supra Part II.A.2 (contrasting property law entitlements with contract-based rights).

${ }^{97}$ This Article is not the first to appreciate the potential relevance of the endowment effect to legal policy. For earlier discussions, see Jack M. Beermann \& Joseph William Singer, Baseline Questions in Legal Reasoning: The Example of Property in Jobs, 23 GA. L. REV. 911, 957-67 (1989); Herbert Hovenkamp, Legal Policy and the Endowment Effect, 20 J. LEGAL STUd. 225 (1991); Mark Kelman, Consumption Theory, Production Theory, and Ideology in the Coase Theorem, 52 S. CAL. L. REV. 669, 678-85 (1979); Duncan Kennedy, Cost-Benefit Analysis of Entitlement Problems: A Critique, 33 STAN. L. REV. 387, 401-21 (1981); Richard S. Markovits, Duncan's Do Nots: Cost-Benefit Analysis and the Determination of Legal Entitlements, 36 STAN. L. REV. 1169, 1179-82 (1984); Stewart Schwab, A Coasean Experiment on Contract Presumptions, $17 \mathrm{~J}$. LEGAL STUD. 237, 260-61 (1988). The articles by Professors Hovenkamp, Kelman, Kennedy, and Markovits deal with assignments of entitlements rather than choices between default rules. For a critique of Hovenkamp's and Markovits's analyses and a proposal of his own, see
} 


\section{The Endowment Effect}

A number of experimental studies have confirmed the existence of the endowment effect. In a wide variety of settings, investigators have found that people tend to demand more to give up an entitlement that they own than they would be willing to pay for that entitlement if they did not own it. One commentator concludes from this research that "the endowment effect appears to be much greater than once thought."

In one well-known experiment, the investigators distributed coffee mugs to one group of students and told them they could exchange their mugs for a large Swiss chocolate bar. ${ }^{99}$ A second group received chocolate bars that were exchangeable for mugs. A third group was simply offered a choice between the mug and the candy. In other words, the first and second groups enjoyed a property right in an exchangeable item, while the third group was asked to choose without reference to an ex ante entitlement position. Of the subjects in the third group, $56 \%$ preferred the mug while $44 \%$ chose the candy bar, ${ }^{100}$ indicating that, in the abstract, the mug and the candy bar were of roughly equal value to them. However, among those who owned a mug, only $11 \%$ chose to trade it for the candy bar. ${ }^{101}$ Similarly, only $10 \%$ of the candy owners preferred the mug. ${ }^{102}$ Ownership appears to make people value what they have more highly than they would if they did not own it and had to pay for it instead.

Russell Korobkin, Policymaking and the Offer/Asking Price Gap: Toward a Theory of Efficient Entitlement Allocation, 46 STAN. L. REV. 663, 676-97 (1994). Professors Beermann and Singer discuss the endowment effect primarily in relation to property rights, but suggest briefly and tentatively its possible relevance to default-rule selection. See Beermann \& Singer, supra, at 973-74. Professor Schwab's paper presents important experimental data bearing on this question, but he touches only briefly on the endowment effect as a possible explanation for his results. See Schwab, supra, at 260-61; infra notes 122-36 and accompanying text (discussing Schwab's research). In a newly published article, Professor Korobkin presents empirical data bearing on the efficiency implications of status quo bias and default rules. See Russell Korobkin, The Status Quo Bias and Contract Default Rules, 83 CoRNell L. REv. 608 (1998) [hereinafter Korobkin, Status Quo Bias]. The present Article is the first to attempt a thorough consideration of the endowment effect and the status quo bias as they relate to the distributive consequences of choices between alternative default rules.

${ }^{98}$ Hovenkamp, supra note 97, at 227.

${ }^{99}$ See Jack L. Knetsch, The Endowment Effect and Evidence of Nonreversible Indifference Curves, 79 AM. ECON. REV. 1277, 1278 (1989).
${ }^{100}$ See id. at 1278.
101 See id.
${ }^{102}$ See id. 
In another experiment, investigators distributed mugs to half of a group of students. ${ }^{103}$ These mug owners were asked to fill out a form indicating the minimum amount of money they would demand in order to sell their mugs. The remaining students, as prospective buyers, were told to indicate the maximum amount they would be willing to pay. Immediately after collecting the forms, the investigators calculated and announced the market-clearing price. ${ }^{104}$ This procedure was then repeated three more times. The purpose of the repetition was to test whether disparities between willing-to-accept and willing-to-pay prices would persist even in market contexts that included opportunities for learning about market prices. ${ }^{105}$ The results of the experiment confirmed that valuation disparities survive even under such circumstances. Median buyer and seller reservation prices remained nearly constant through all four of the markets, with selling prices more than twice as high as buying prices. ${ }^{106}$

A number of other experiments have yielded comparable results. ${ }^{107}$ Experimental data have been consistent with a number of studies that relied on surveys rather than on actual trading. Much of

${ }^{103}$ See Daniel Kahneman et al., Experimental Tests of the Endowment Effect and the Coase Theorem, 98 J. POL. ECON. 1325, 1330-33 (1990).

${ }^{104}$ The price was determined by the intersection of the supply and demand curves. See id. at 1330-31.

${ }^{105}$ It was announced in advance that one of the four markets would be selected at random and all trades would be implemented. See id. This procedure encouraged the subjects to be honest in their valuations in each of the four markets.

${ }^{106} S_{e e} i d$. at 1332 . The markets-for-mugs experiment described in the text above indicates that high willing-to-accept prices can persist even in the face of knowledge that the market price is lower.

${ }^{107}$ For additional experiments, see, for example, David S. Brookshire \& Don L. Coursey, Measuring the Value of a Public Good: An Empirical Comparison of Elicitation Procedures, 77 AM. ECON. REV. 554 (1987); Kahneman et al., supra note 103, at 1333-42; Knetsch, supra note 99, at 1279-81; Jack L. Knetsch \& J.A. Sinden, Willingness to Pay and Compensation Demanded: Experimental Evidence of an Unexpected Disparity in Measures of Value, 99 Q.J. ECON. 507 (1984) [hereinafter Knetsch \& Sinden, Willingness to Pay]. For a useful summary of experimental findings of valuation disparity in tabular form, see Kahneman et al., supra note 103 , at 1327 tbl.1. Under certain highly artificial circumstances, subjects' willing-to-accept and willing-to-pay prices may converge after repeated transactions. See Don L. Coursey et al., The Disparity Between Willingness to Accept and Willingness to Pay Measures of Value, 102 Q.J. ECON. 679, 682-89 (1987) (discussing an experiment involving the tasting of an extremely unpleasant substance). These results have been criticized. See Jack L. Knetsch \& J.A. Sinden, The Persistence of Evaluation Disparities, 102 Q.J. ECON. 691 (1987) (pointing out, inter alia, that disparities persisted even in the experiment discussed in Coursey et al., supra). For a general discussion of experimental data on the endowment effect, see Daniel Kahneman et al., The Endowment Effect, Loss Aversion, and Status Quo Bias, J. EcoN. PERSP., Winter 1991, at 193, 194-99. 
this work has involved the valuation of environmental goods. ${ }^{108}$ For example, hunters who were questioned about the possible loss of a duck habitat said that they would demand an average of $\$ 1044$ to accept the loss, but would be willing to pay an average of only $\$ 247$ to prevent it. ${ }^{109}$ In another survey, subjects were surveyed regarding various levels of air-quality deterioration. ${ }^{110}$ They indicated that they would require from five to sixteen times more compensation to accept this loss than they would be willing to pay to avoid it.

The general point that emerges from this substantial body of research is that people tend to demand more to give up an entitlement than they would be willing to pay in order to acquire it. "Thus, money or assets that are considered by individuals to be part of their endowment seem to be valued more highly-it takes a more advantageous offer for them freely to give them up-than money or assets that are not considered to be included in their present endowment."111 Differences between willing-to-accept and willing-to-pay measures of value often appear to be quite substantial-too substantial to be attributed entirely to wealth or income effects. ${ }^{112}$ Valuation is context-driven, with a person's existing endowment serving as a powerful reference point. ${ }^{113}$

${ }^{103}$ See, e.g., R.G. CUMmings ET AL., VALUING ENVIRONMENTAL GOODS (1986); JUDD HAMMACK \& GARDNER MALIARD BROWN, JR., WATERFOWL AND WETLANDS (1974); Philip A. Meyer, Publicly Vested Values for Fish and Wildlife: Criteria in Economic Welfare and Interface with the Law, 55 LAND ECON. 223 (1979); Robert D. Rowe et al., An Experiment in the Economic Value of Visibility, $7 \mathrm{~J}$. ENVTL. ECON. \& MGMT. 1 (1980); William D. Schulze et al., Valuing Environmental Commodities: Some Recent Experiments, 57 LAND ECON. 151 (1981).

109 See HAMMACK \& BROWN, supra note 108, at 26-27.

110 See Rowe et al., supra note 108, at 1-3.

${ }^{11}$ Knetsch \& Sinden, Willingness to Pay, supra note 107, at 516 (citing Richard Thaler, Toward a Positive Theory of Consumer Choice, 1 J. ECON. BEHAV. \& ORG. 39, 43-47 (1980)). In other words, marginal utility curves for money (and other assets and entitlements) appear to have a "kink" at the point of an individual's current level of wealth. The curve slopes much more steeply to the left of that point than it does to the right, indicating that people weigh subtractions much more heavily than additions. See Hovenkamp, supra note 97, at 228 ("[T] he burden of a downward shift in one's standard of living is felt more heavily than is the benefit of an upward shift of the same dollar amount.").

112 See Knetsch \& Sinden, Willingness to Pay, supra note 107, at 516 (“[T] he magnitude of the values at issue should rule out the income or wealth effect as being an adequate explanation of the observed variation between the two measures."). Wealth effects in the experiments described in the text above presumably were insignificant.

${ }^{115}$ One implication of the endowment effect is that an individual's indifference curve as to two goods is nonreversible, contrary to a basic assumption of neoclassical welfare economics. If a person's valuation of a good depends on whether he or she owns it, exchange rates between that good and another will depend on whether the 
The reasons for the endowment effect remain uncertain. Investigators have speculated that people assess change by reference to existing circumstances and conditions, including their current endowment of wealth. ${ }^{14}$ Opportunities for trade represent departures from these reference points. More specifically, such changes are evaluated as gains or losses relative to a reference point, rather than simply as opportunities to exchange particular goods for more highly valued goods. ${ }^{115}$ For instance, when selling items of value, people behave as if such changes represent a loss relative to their current endowments. Accordingly, they demand a higher price as compensation than they would be willing to pay to acquire the same assets if they did not own them. Acquisition represents an increase in wealth relative to the reference point, but the increase is not valued as highly as the perceived loss. Knetsch and Sinden suggest that this phenomenon illustrates a psychological disposition to guard against future regret. The possibility of regret, evidently more potent when assessing potential losses than potential gains, is a cost that is factored into calculation of selling prices. ${ }^{116}$

More generally, people seem to have a strong tendency to prefer the status quo. A multipart questionnaire administered by Professors Samuelson and Zeckhauser revealed that, given a choice between alternatives both involving departure from the status quo, people behave differently than when the choice is between maintaining the status quo and moving to an alternative. ${ }^{117}$ For example, one set of Samuelson and Zeckhauser's questions instructed the subjects to choose among several investment alternatives. Remaining with a current investment was not among the choices; in this sense, all choices were neutral or on the same footing. Another group was given a choice between retaining their current portfolios or choosing among the same menu of options offered to the first group. The percentage of respondents favoring a particular choice was highest when it was in the status quo position and lowest when it was framed

exchange rates between that good and another will depend on whether the person is giving up or acquiring the good in question. See Knetsch, supra note 99, at 1282-83.

11 See Knetsch \& Sinden, Willingness to Pay, supra note 107, at 516-17.

${ }^{115}$ See Kahneman et al., supra note 107, at 199.

${ }^{116}$ See Knetsch \& Sinden, Willingness to Pay, supra note 107, at 517.

117 See William Samuelson \& Richard Zeckhauser, Status Quo Bias in Decision Making, 1 J. RISK \& UNCERTAINTY 7, 8 (1988) (concluding that "decision makers exhibit a significant status quo bias"). 
as an alternative to the status quo. When offered as a neutral alternative, the response rate was intermediate between these two. ${ }^{118}$

Another study drew conclusions from an analysis of two groups of electricity consumers. ${ }^{119}$ One group lived in an area with reliable service but relatively high prices; the other lived in an area with less reliable service but lower rates. When surveyed about their preferences as between several combinations of varying levels of reliability and price, approximately $60 \%$ of the consumers in each group preferred to remain with the status quo of their own group, while only approximately $6 \%$ chose the status quo of the other group. ${ }^{120}$ The endowment effect, which leads people to value assets more highly if they own them than if they are considering buying them, appears to be an instance of this more general preference for the status quo.

\section{Default Rules as Endowments}

Even if the endowment effect applies to valuation of entitlements, it is not at all clear that it is relevant to rights specified by contractual default rules. This is because, as discussed above, ${ }^{121}$ contractual default rules themselves do not create entitlements. The right or duty specified by a default rule becomes effective only if the term is embodied in a contract. Further, the party burdened by the right must agree to take up the burden, so the beneficiary explicitly or implicitly pays for the benefit. This is important because, although default rules are biased in favor of particular classes of individuals, the beneficiaries of such biases do not necessarily gain any value by virtue of that bias.

More concretely, a job-security default rule would not itself confer job security on workers. Employers would have to agree to hire workers on that basis, and, if they did, workers would have to pay for the benefit in the form of a lower wage. Further, if at-will employment were more efficient than job security (and transaction costs were not excessive), the parties would contract around the default rule anyway. Because a job-security default rule would not create an entitlement,

${ }^{118}$ See id. at $14-15$ (finding in the results "an obvious and revealing pattern" of favoring the status quo). Five other studies structured in a similar manner produced the same conclusions. See id. at 19-26 (reporting the results of the surveys).

${ }^{119}$ See Raymond S. Hartman et al., Consumer Rationality and the Status Quo, 106 Q.J. ECON. 141, 158-61 (1991).

${ }^{120}$ See id. at 149. Each group possessed similar demographic, income, and electricity-consumption characteristics. See id. at 154.

121 See supra Part II.A.2. 
the endowment effect would not necessarily have any bearing on the wealth of workers if job security replaced at-will as the default rule.

Even though default rules do not represent endowments, there is evidence that people behave as if they do. Valuations of potential contract terms seem to differ according to whether a term enjoys default-rule status. Further, when engaged in contract negotiations, beneficiaries of a right specified by a default rule appear to achieve better results than if the default rule were the opposite.

This advantage is evident in an important article by Professor Schwab reporting the results of a carefully designed experiment simulating bargaining in the labor context. ${ }^{122}$ Two hundred twenty students from two classes were divided into two groups, one group representing a union and the other an employer. Individual union and employer negotiators were paired with each other. The pairs were then broken down into two sets. One set of parties bargained against the background of a default rule that forbade the employer to transfer work from a union to a nonunion plant; for the other set, the default rule allowed transfer. ${ }^{123}$ Pairs of bargainers were instructed to reach an agreement regarding wages, number of vacation days, and the employer's right to transfer work. Individual students received "preference sheets" specifying the number of points that could be earned for various bargaining outcomes. The objective was for each bargainer to obtain a contract including as many points as possible. The investigators did not provide the students with information about their counterparts' preferences. ${ }^{124}$

Schwab found that $80 \%$ of the 108 completed contracts failed to maximize fully the available gains from trade. ${ }^{125}$ These results, therefore, did not support the hypothesis that bargainers would always reach the optimally efficient outcome regardless of the default rule. The choice between alternative default rules, however, had no effect

${ }^{122}$ See Schwab, supra note 97 , at 238.

${ }^{123}$ See Milwaukee Spring Div. of Ill. Coil Spring Co., 265 N.L.R.B. 206, 208-10 (1982) (presumptively forbidding transfer), rev'd on reh'g, 268 N.L.R.B. 601, 601 (1984) (presumptively allowing transfer), affd sub nom UAW v. NLRB, 765 F.2d 175, 184 (D.C. Cir. 1985) (affirming the decision of the NLRB because the company "acted without antiunion animus for purely economic reasons and fulfilled any statutory obligations to bargain that it might have had").

${ }^{124}$ See Schwab, supra note 97, at 246-49.

${ }^{125}$ See id. at 251. 
on whether the parties reached efficient agreements; they were just as likely to do so under either default-rule regime. ${ }^{126}$

Although differences in the work-transfer default rule had no impact on efficiency, they did have significant distributive consequences. When the default was a prohibition on the employer transferring work from a union to a nonunion production facility, the resulting contracts were significantly more favorable to the union than when the default rule was the opposite. That is to say, the union negotiators ended up with more points when no-transfer was the default rule. ${ }^{127}$ Correspondingly, employers did significantly better when the default rule allowed freedom of transfer. ${ }^{128}$ This was true regardless of whether the specified preferences indicated that a right to transfer was efficient or inefficient.

The default rule allowed the party it favored to achieve a better outcome than if the default were biased the other way. The notransfer default, however, did not benefit workers by making it more likely that actual contracts would contain a no-transfer term. The parties tended toward efficient outcomes, which did not necessarily include the term expressed by the default rule. ${ }^{129}$ Nevertheless, when no-transfer was the default rule, workers earned a larger share of the gains from trade. ${ }^{130}$ The default rule, although it did not create an entitlement, did appear to confer bargaining leverage on the party it favored. Schwab concludes that "the contract presumption increases bargaining power. Bargainers do better when the contract presumption favors them."

${ }^{126}$ See id. at 252-53. The investigators assigned points to various bargaining outcomes such that under one scenario, the no-transfer clause was efficient while under the other scenario, the freedom-to-transfer clause was efficient. The contract term restricting transfer would be efficient if the instructions specified that the union valued the restriction on the employer's right more highly than the employer valued freedom-to-transfer. Conversely, a contract term allowing transfer would be efficient if the employer valued it more highly than the union valued a no-transfer alternative term. See id. at 249.

${ }^{127}$ See id. at 254.

${ }^{128}$ See id. at 255.

${ }^{19}$ See id. at 257 (concluding that "these bargainers seem driven toward efficiency rather than toward the presumption").

${ }^{130}$ As indicated in table four, the union earned a mean of 1278 points under the no-transfer default, but only 1192 under the opposite default rule. The employer achieved correspondingly better results when the default rule allowed transfer. See id. at 254 tbl.4 (stating that the management team achieved 1774 points when right-totransfer was the default and 1696 when it was not).

131 Id. at 257. 
Although Schwab offers some suggestive speculations, ${ }^{132}$ the reasons for his results are not clear. It is possible that the endowment effect is at work. ${ }^{133}$ When the contract term expressed by the default rule was not efficient, the parties tended to pursue the efficient alternative. However, they behaved as if the default rule's presumption was an asset that its beneficiary had to be persuaded to sell to the other party. So, when the efficient contract term was right-to-transfer but the default was no-transfer, union negotiators could insist on compensation for "giving up" the default term. If instead the default allowed transfer, they owned no "right" that they could sell to the employer, and therefore gained less from the resulting contract. ${ }^{134}$ As Schwab puts it, "bargainers in this experiment acted as if they must purchase the right when the legal presumption favored the other party and thus were in a weaker bargaining position." ${ }^{\text {"35 }}$

When the default rule was also the efficient contract term, the parties similarly acted as if the law endowed the rule's beneficiary with an asset. If a no-transfer contract term was efficient and was the default rule, the employer was apparently less able to make the union pay for that benefit (presumably in the form of a lower wage) because, in effect, the union already "owned" it. However, if the default was right-to-transfer, the union was perceived by the parties as having to buy the no-transfer right from the employer. Even though the parties moved toward the efficient contract term in all cases, the choice between default rules made a difference. The rule's bias functioned as an entitlement and thereby improved bargaining outcomes for the rule's beneficiaries. ${ }^{136}$

Another experimental study provides further support for Schwab's findings on the tendency of bargainers to regard default rules as entitlements. ${ }^{137}$ In a study of consumer decisions about

${ }^{132}$ See id. at 256-61 (attributing the results to the peculiarities of the labor context or, in the context of bargaining in general, the signaling or value-enhancing effects).

${ }^{139} C f$. id. at 260 (positing a "general hesitation effect' of contract presumptions," under which parties are generally hesitant to waive presumptions that are "theirs").

134 When a right-to-transfer term was efficient but no-transfer was the default, Schwab's union negotiators achieved a mean of 1229 points; when right-to-transfer was the default, however, they realized a mean of only 1137 points. See id. at 254 tbl.4.

${ }^{135} I d$. at 254.

${ }^{196}$ When no-transfer was both the efficient contract term and the default rule, the union negotiators earned a mean of 1320 points. However, when no-transfer was the default, they realized a mean of only 1250 points. See id. at 254 tbl.4.

${ }^{137}$ See Eric J. Johnson et al., Framing, Probability Distortions, and Insurance Decisions, 7 J. RISK \& UNCERTAINTY 35, 46-48 (1993). 
automobile liability insurance, the study's investigators divided the subjects into three groups. Members of one group were asked to imagine that they had just moved to a new state and had to choose between two standard policies: one that gave the insured the full right to sue for auto-related injuries, and another that restricted that right but cost $11 \%$ less. ${ }^{138}$ In contrast to this neutral choice, the other two groups were told that the standard insurance policy included either an unlimited or limited right to sue as the default option. Members of these groups were asked whether they would be willing to reject the default term and select the nonstandard alternative instead. Of those for whom the unrestricted right to sue was the default, $53 \%$ preferred to retain that right. ${ }^{139}$ In contrast, when the default was a limited right to sue, only $23 \%$ chose to acquire the full right. ${ }^{140}$ Members of the full-right default group indicated that they were willing to pay an average of $32 \%$ more for the full right, while the limited-right group was willing to pay no more than an average of $8 \%$ to acquire that right. ${ }^{141}$

Data regarding actual insurance decisions tend to confirm these experimental findings. ${ }^{142}$ In Pennsylvania, recent insurance law changes provide a full right to sue as the default option. In contrast, New Jersey offers a limited right to sue as the default, with the opportunity to acquire the full right for a higher premium. Only about $20 \%$ of New Jersey consumers have chosen the full right to sue, while approximately $75 \%$ of Pennsylvanians have retained that right. ${ }^{143}$

Like the subjects in Schwab's study, actual consumers behave as if the full right to sue is worth more when embodied in a default rule than when the default rule is the opposite. In Pennsylvania, a significant majority prefers the right to sue even though they must pay a higher premium for it. For residents of New Jersey, however, the same right is not worth the extra cost. If Schwab's findings are typical, such valuation differentials should affect actual bargaining outcomes. Pennsylvanians ought to end up with a better package of coverage and price because, as "owners" of an "entitlement" con-

${ }^{13 s}$ See id. at 47 .

${ }^{199}$ See id.

${ }^{140}$ See id.

${ }^{141}$ See id. For the neutral group, $48 \%$ preferred the full right to sue and were willing to pay an average of $23 \%$ more for policies including that right than they would for a restricted right-to-sue policy. Seeid.

${ }^{142}$ See id. at 48 .

${ }^{143}$ See id. Note that the observed differential is actually larger than that yielded by the hypothetical study. 
ferred by law, consumers and insurance companies alike should behave as if the consumers do not have to pay as much for the right as they would if the opposite default rule were in effect. Given the observed differences in valuation, one would expect that these different default-rule choices have left Pennsylvanians better off than their counterparts on the other side of the Delaware River. ${ }^{144}$

A recently published experimental study by Professor Korobkin provides further evidence of the tendency to value contract terms more highly when they enjoy default-rule status. Korobkin asked law students to assume the role of attorneys advising a client (an overnight package delivery service) about the desirability of various contract terms. ${ }^{145}$ In three scenarios, subjects were presented with default rules and asked how much they would recommend that the client demand in return for agreeing to terms overriding the defaults. In each situation, the subjects showed a marked preference for the terms expressed as default rules. Thus, where the default was the familiar Hadley v. Baxendale foreseeability limitation on damages liability, subjects recommended significantly higher compensation for an unlimited damages term than they were willing to pay in order to add the limitation to avoid an unlimited damages default. ${ }^{146}$ The subjects behaved similarly when the issue was whether impossibility should excuse nonperformance ${ }^{147}$ and also when the issue was whether, in case of litigation, each party should pay its own attorneys' fees or whether instead the losing party should pay the fees of the winner. ${ }^{148}$

${ }^{144}$ It would be interesting to compare the premiums paid by Pennsylvania insureds with those of New Jersey policyholders who chose the right-to-sue option. However, it would be necessary to keep in mind that many factors other than differences in valuation of the right to sue could explain premium variations. Various factors might combine to make motor vehicle ownership and operation more risky in New Jersey than in Pennsylvania, resulting in higher insurance premiums for similar coverage. As it happens, New Jersey residents pay the highest prices for automobile insurance in the United States. See Devon Spurgeon, Auto Insurance Is Driving Force in N.J. Election, WASH. POST, Oct. 25, 1997, at A4.

145 See Korobkin, Status Quo Bias, supra note 97, at 634-36.

${ }^{146}$ The subjects recommended an average minimum of $\$ 6.96$ per package to waive the foreseeability limitation default. In contrast, where unlimited damages was the default, they counseled the client to pay no more than $\$ 4.46$ to add the limitation. See id. at 639.

${ }^{147}$ The subjects demanded a minimum of $\$ 302,000$ to accept elimination of the excuse where the default rule was impossibility as an excuse but were willing to pay no more than $\$ 78,000$ to add an impossibility term to the contract. Seeid. at 643 .

${ }^{148}$ When the default rule required parties to pay their own expenses, $59 \%$ of the subjects preferred that term while, when the default was loser-pays, only $28 \%$ perferred the each-party-pays-its-own-expenses term. See id. at 647 tbl.1. In this scenario, 
Like Schwab's simulated labor negotiations and the automobile insurance experiment, Korobkin's study demonstrates that valuations of contract terms are influenced by whether terms are embodied in default rules, even though the objects of exchange are not actual property entitlements. ${ }^{149}$

The research discussed here strongly suggests that the endowment effect and status quo bias apply to rights specified in default rules as well as to actual entitlements. Workers would be better off if job security were the default rule, because they would value that right more highly than they do under the current at-will regime. In practical terms, this means that even if workers ended up with employmentat-will contracts, they could expect a higher wage than they receive under the current at-will default regime because they would obtain compensation for "waiver" of the job-security default term. Employers, too, would expect to pay a higher wage to induce workers to contract around the default. If bargaining instead resulted in employment contracts that retained the job-security default term, workers also would be better off than they are under the at-will default. Both parties would behave as if workers already "owned" the jobsecurity right and therefore did not have to buy it from employers, thus pushing wages higher than if at-will were the default rule. In short, contrary to economic orthodoxy, changing the current default rule to job security could have significantly favorable distributive consequences for workers.

The analysis offered here is not limited to the choice between atwill and job-security default rules. Those interested in improving the bargaining position of other nonshareholder constituencies might resort to the same strategy. For example, the limited-liability default rule could be changed to a presumption of unlimited liability. Contract creditors would stand to improve their positions because they

Korobkin also provided a third, neutral situation in which the rule required a contract to include one term or the other. The distribution of the subjects' preferences as between the two alternatives was markedly different from that resulting from the loserpays default, indicating the influence of the default rule on the subjects' preferences. The distribution resulting from the each-party-pays default was similar to that resulting from the neutral situation, which Korobkin suggests was due to the subjects' tendency to regard each-party-pays as if it were in fact the default option in either case. Seeid. 631.

Korobkin refers to these quasi-entitlements as "illusory endowments." Id. at 
would capture a larger share of gains from trade. ${ }^{150}$ I find the case for protecting contract creditors less compelling than the case for worker protection, because the bargaining capability argument deployed above $^{151}$ is less applicable to creditors than to workers, at least as a general proposition. Even so, however, it should be clear now that the current tidal wave of legislation extending limited liability to small businesses ${ }^{152}$ is not a benign development as between contract creditors and business owners. Extension of limited liability obviously prejudices the interests of future tort victims even further than corporate law's current legal regime does. ${ }^{153}$ What has gone unappreciated are the negative distributive consequences for contract creditors, too.

\section{The Endowment Effect and Market Efficiency}

Because owners of entitlements place a higher value on them than do prospective buyers, the endowment effect can lead to fewer trades of such entitlements than would occur if valuation were independent of ownership. ${ }^{154}$ As the gap between buyers' and sellers' valuations widens, the possibility of a mutually advantageous trade diminishes. If a job-security default rule really would lead workers to value that right more highly than they do now, is it possible that they would value that term so highly as to reduce the ability of workers and employers to reach employment agreements? Such a result seems unlikely for two reasons.

First, changing the default rule would not necessarily lead to a lower number of employment contracts, because the higher value that workers would place on job security might offset the higher value that employers currently place on the at-will contract term under the at-will default regime. Workers would demand higher prices for atwill contracts, but employer reservation prices would also increase because employers would no longer "own" the at-will "entitlement"

${ }^{150}$ Tort creditors might gain even more, because the absence of bargaining would prevent corporate tortfeasors from attempting to make potential tort victims pay for the benefit of unlimited liability ex ante.

151 See supra Part I.D.1.

${ }^{152}$ See supra note 70 and accompanying text.

${ }^{159}$ On the inefficiency of limited liability as to tort creditors, see, for example, Henry Hansmann \& Reinier Kraakman, Toward Unlimited Shareholder Liability for Corporate Torts, 100 YALE L.J. 1879, 1879-81 (1991), and David W. Leebron, Limited Liability, Tort Victims, and Creditors, 91 COLUM. L. REV. 1565, 1584 (1991).

${ }^{134}$ See Kahneman et al., supra note 103, at 1326-29 (discussing the endowment effect and market efficiency). 
conferred by the default rule. Likewise, employers would be willing to pay a higher wage under a job-security contract because workers would no longer have to "buy" the job-security term. Even though there is no reason to assume that the effects of the default-rule change on employer and worker valuations would offset each other precisely, it still seems possible that market efficiency would be largely unaffected.

In addition, there is a built-in safeguard against workers valuing job security so highly as to prevent them from accepting higher-wage offers within the price range acceptable to employers. Pricing of default rules differs from pricing of consumer goods and other property rights in an important way. As discussed previously, a default rule confers no actual value on its beneficiary; its value depends on the ability to incorporate it into a contract or to waive it-on favorable terms in either case. A worker, therefore, does not have a meaningful choice between "keeping" the default rule and exchanging it for something else. Refusal to exchange means unemployment, and the existence of a favorable default rule provides no substitute for the benefits that go with work. In this respect, the worker differs from the owner of an asset that may be consumed or invested. The owner may be better off by declining a trade that offers less value than retention of the asset in question. Accordingly, even though a job-security default rule might well improve bargaining outcomes for workers, the nature of the value that it creates is not likely to have the same kind of effect on trading behavior that reassignment of a genuine entitlement might have. Workers have a powerful incentive to adjust their valuations of job security to facilitate agreements with employers. Reversal of the endowment effect should lead employers to offer higher wages whether the employment contract is to include an at-will or a jobsecurity term. Workers will seize the benefits of these higher offers rather than pricing themselves out of the market. Workers therefore stand to be better off than under the current default-rule regime, and there need be no reduction in the volume of employment contracting.

$$
* * * *
$$

In this Part, I have presented an argument for changing the current at-will default rule to a job-security default rule as a law reform strategy. Choices between alternative default rules can have an impact on wealth distribution, though not for the reason that property entitlements do. Rather, the endowment effect and status quo bias appear to affect contracting behavior by influencing valuation of the 
rights expressed by default rules. As a result, beneficiaries of default rules stand to realize larger shares of gains from trade even though default rules themselves do not confer entitlements.

\section{DEFAULT RULES AND EFFICIENCY}

The previous Part argued that a job-security default rule could assist workers in obtaining a larger share of gains from trade in employment contracts. As discussed, this outcome is possible whether contracts end up including an at-will or a job-security term. If the default rule is job security but it turns out that an at-will term is more efficient, the parties will seek to include an at-will term in their contract. For those who do, there will be costs involved in contracting around the job-security default. It is conceivable that the workers' share of these transaction costs could exceed the distributive gains brought about by the job-security default rule. In that case, workers would be worse off than they would be with an at-will default rule. ${ }^{155}$

Again assuming that an at-will contract term is superior to a jobsecurity term, it is also possible that the costs involved in contracting around a job-security default could be high enough to prevent workers and employers from obtaining the superior contract term. In that case, workers would not necessarily incur significant transaction costs, ${ }^{156}$ but the efficiency loss conceivably could be greater than the amount by which the workers' share of the gains from trade under a job-security default would exceed what they would have realized under an at-will default rule. ${ }^{157}$ Both of the possibilities suggested here consider the potential impact of transaction costs on worker well-being. Either provides an argument against switching to a job-

${ }^{155}$ By way of a simple example, assume that an at-will term is more efficient than a job-security term. Assume further that, under an at-will default rule, workers would receive $\$ 12$ per hour for an at-will contract but only $\$ 9$ for a contract including a jobsecurity term. If, in contrast, the default rule were job security, assume that the endowment effect would result in workers receiving $\$ 13$ and $\$ 10$ for at-will and jobsecurity contracts, respectively. In the job-security default-rule scenario, if transaction costs are less than the amount of the wage differential, the parties will contract on an at-will basis and workers will receive $\$ 13$. However, transaction costs might still be high enough that the net value of the resulting contract would be less than what it would have been under an at-will default-rule regime (\$12).

${ }^{136}$ Of course, bargaining over an at-will term without reaching agreement would involve transaction costs.

${ }^{157}$ Simplifying again (and referring to the values used in note 155, supra), if transaction costs are high enough to block adoption of an at-will term when the default is job security, workers will find themselves with a contract worth $\$ 10$. If the default rule had been at-will, they could have received $\$ 12$. 
security default even if one seeks to enhance workers' wealth by means of the analysis advanced in Part II above. ${ }^{158}$

There are two possible responses to these arguments for retaining the at-will default rule. First, one may question whether the costs involved in moving from a job-security default to an at-will contract term likely would be significant in magnitude. I think it is reasonably likely that they would not be. This is not a situation where the parties must create a customized contract term out of whole cloth. Instead, long experience has given the at-will contract term reasonably definite meaning. By including language to the effect that employment shall be at-will according to the common law understanding of that phrase, parties can readily adopt the traditional contract term by a simple reference to it. Under these circumstances, the at-will alternative to a job-security default would function as an easily selected "offthe-rack" option.

Another response to the transaction cost savings argument for an at-will default rule would question whether there is good reason to assume that at-will employment is more efficient than job security. In the remainder of this Part, I consider the most obvious argument in favor of at-will's superior efficiency. Simply put, its prevalence in this country in actual contracting practice assertedly provides powerful evidence of its efficiency. If, however, the status quo does not deserve a presumption of superiority, some other argument would be needed. Absent such an argument, there would be no basis for retaining the at-will default rule because of its superior efficiency. For the reasons discussed below, I conclude that the efficiency question is far more uncertain than it is typically assumed to be. In particular, recent research casts serious doubt on the status quo's presumed efficiency. ${ }^{159}$ That being so, I suggest that concerns about the efficiency effects of a change in the default rule should not deter efforts to realize the potential distributive benefits already considered.

\section{A. Default Rules and Transaction Cost Savings}

If a particular contract term is likely to be beneficial for most people, it makes sense for the law to incorporate that term in a de-

${ }^{158}$ Note, however, that if job security is more efficient than at-will employment, a job-security default rule would eliminate one source of transaction costs in addition to altering the distribution of gains from trade.

${ }^{159}$ Recent economic research also indicates the possible superiority of job security, see supra note 89. 
fault rule, because default status saves the parties the costs involved in contracting around a less-favored alternative. For example, if both workers and employers typically favor at-will status but the default rule is job security, costs may be involved in drafting appropriately welltailored at-will terms. ${ }^{160}$ Failure to do the job well enough may leave one or the other party disappointed if they reach agreement as to certain rights and duties but fail to specify those rights completely. Where there is no agreement on an issue, vagueness creates uncertainty about the future. Parties who would prefer at-will, but for some reason overlook the existence of a job-security default, bear the costs of their oversight. The same considerations would apply under the current default-rule regime if job security were more efficient than atwill. If efficiency is the objective, both contracting parties generally stand to benefit if the default rule is the term they would choose for themselves.

This is not the only way in which default-rule choice can promote efficiency. Under certain circumstances, default rules can alleviate informational asymmetries that lead to suboptimal bargains by inducing a party to reveal information that would otherwise be unavailable to the other party. ${ }^{161}$ In the employment context, a job-security default rule might enhance efficiency by facilitating signaling strategies that reveal information about prospective workers. ${ }^{162}$ Despite the

${ }^{160}$ See, e.g., POLINSKY, supra note 80, at 27.

${ }^{161}$ See Ian Ayres \& Robert Gertner, Filling Gaps in Incomplete Contracts: An Economic Theory of Default Rules, 99 YALE L.J. 87, 97 (1989) ("[P]enalty default rules can be justified as a way to encourage the production of information.").

${ }^{362}$ At the time of contract formation, the value of an employment relationship to the employer depends on the worker's future effort. Employers typically are in the dark about whether a prospective worker is a high-effort type, a low-effort type, or somewhere in the middle. Readily observable traits are not revealing, and reputational data either will be unavailable or costly to acquire and of possibly doubtful reliability. Because workers presumably know their own type, there exists an informational asymmetry. (The asymmetry potentially is bilateral because workers may lack knowledge about the propensity of a prospective employer to engage in opportunistic discharge, but reputational data may be more reliable on this question, and the informational asymmetry therefore less prominent.)

Unable to discriminate according to effort type, the employer pays a single wage that reflects the distribution of high- and low-effort types in the relevant worker population. This weighted average will be lower than the wage that would be paid to high-effort workers alone, and higher than what low-effort workers alone would receive. It is termed a "pooling equilibrium." Under such circumstances, high-effort workers have an incentive to identify-or "signal" - their type to prospective employers in order to improve their earnings. Effective signaling may be difficult, however, because it requires that the cost of acquiring and deploying the signal be lower for the type of worker identified by the signal than for others. Absent such a cost differential, 
potential relevance of these ideas, my focus here is on the argument for the at-will default rule's superior efficiency based on the prevalence of at-will employment in actual contracting practice.

\section{B. Efficiency and the Status Quo}

\section{The Efficiency of the Status Quo}

Law-and-economics scholarship has often assumed that the status quo is, or at least tends to be, more efficient than its alternatives. ${ }^{163}$

high- and low-effort types can both use the signal, making it impossible for the former to separate themselves from the latter. See generally Michael Spence, Job Market Signaling, 87 Q.J. ECON. 355 (1973). If an effective signaling strategy is feasible, a "separating equilibrium" can emerge, according to which high- and low-effort workers are paid different wages according to their respective value to the firm.

My suggestion is that, if job security were the default rule, offering to work on an at-will basis may be a way for high-effort workers to signal their type. This is based on the intuition that high-effort workers should be more willing to accept at-will employment than low-effort workers because high-effort workers are less concerned about the employer's freedom to discharge. High-effort workers presumably believe themselves to be less likely to be fired for shirking or other malfeasance because they do not expect to engage in such behavior. Low-effort workers, in contrast, value more highly the protection afforded by a job-security contract term. The difference in cost of atwill employment suggests that offering to work on an at-will basis could be a feasible signaling strategy. If so, a more efficient separating equilibrium could be the result.

Besides facilitating valuable information revelation, a job-security default might also avoid existing incentives against information revelation. The current at-will default may discourage workers from seeking job security because a request for a jobsecurity contract term could be interpreted as a signal that a worker values security in order to be able to engage in shirking behavior. See Walter Kamiat, Labor and Lemons: Efficient Norms in the Internal Labor Market and the Possible Failures of Individual Contracting, 144 U. PA. L. REv. 1953, 1958 (1996) ("[A]n individual may value [job-security] protection precisely because she expects (or wishes to reserve an option) to perform deficiently at the job in question ....").

${ }^{163}$ This assumption presupposes that if actors are adequately informed, they will enter into contracts that maximize their utility. If one contract term is more valuable than another, they will select that term rather than the inferior one, within the constraints imposed by the necessity of obtaining each other's consent. Insufficient information about the value of the various alternatives is a potential impediment to utility maximization, but contracting parties do not have to make choices in a vacuum. They have the benefit of society's accumulated experience as a source of instruction. An evolutionary process analogous to natural selection has tended to weed out inefficient possibilities.

One commentator describes the law-and-economics notion of legal evolution in these terms: "The basic thesis is that people share a desire to eliminate unnecessary costs, and that over time the shared goal of reducing unnecessary costs causes the law to evolve toward rules of law that are less wasteful or, conversely, rules that increase economic efficiency." E. Donald Elliott, The Evolutionary Tradition in Jurisprudence, 85 COLUM. L. REV. 38, 62-63 (1985). Law-and-economics scholars differ in their under- 
This assumption is apparent in Professor Epstein's well-known article on at-will employment. ${ }^{164}$ His starting point is the assertion that "[t]he survival of the contract at will, and the frequency of its use in private markets, might well be taken as a sign of its suitability for employment relations." ${ }^{165}$ There is no legal barrier to workers negotiating for job security, so it seems reasonable to infer that employment at will is as common as it is because both workers and employers prefer at-will contract terms over job security. In Epstein's words, "[i]t is simply incredible to postulate that either employers or employees, motivated as they are by self-interest, would enter routinely into a transaction that leaves them worse off than they were before, or even worse off than their next best alternative."166 Having assumed the efficiency of at-will employment from its prevalence in actual contracting practice, Epstein then proceeds to offer several reasons why workers and employers choose employment at will as often as they do. ${ }^{167}$ "[T] he task is to explain how and why the at-will contracting arrangement (in sharp contrast to slavery) typically works to the mutual advantage of the parties."

It is important to see that Epstein's form of argument does not demonstrate the superiority of at-will employment. Superiority is

standings of the mechanisms that actually drive the selection process. See, e.g., Robert Cooter \& Lewis Kornhauser, Can Litigation Improve the Law Without the Help of Judges?, 9 J. LEGAL STUD. 139 (1980) (providing a model for the improvement of the law over time through an evolutionary process unguided by judicial insight); George L. Priest, The Common Law Process and the Selection of Efficient Rules, 6 J. LEGAL STUD. 65 (1977) (asserting that the tendency of legal rules to become efficient over time is independent of judicial decisionmaking); Paul H. Rubin, Why Is the Common Law Efficient?, $6 \mathrm{~J}$. LEGAL STUD. 51 (1977) (concluding that efficiency in the law occurs because parties will litigate inefficient rules more often than efficient rules). For a recent study of theories of biological evolution and their possible relevance to an understanding of legal change, see J.B. Ruhl, The Fitness of Law: Using Complexity Theory to Describe the Evolution of Law and Society and Its Practical Meaning for Democracy, 49 VAND. L. REV. 1407 (1996).

${ }^{164}$ See Epstein, supra note 91.

${ }^{165}$ Id. at 948; see also Mayer G. Freed \& Daniel D. Polsby, Just Cause for Termination Rules and Economic Efficiency, 38 EMORY L.J. 1097, 1098 (1989) (asserting that the prevalence of at-will employment indicates its efficiency); J. Hoult Verkerke, $A n$ Empirical Perspective on Indefinite Term Employment Contracts: Resolving the Just Cause Debate, 1995 WIS. L. REV. 837, 87475 (same).

${ }^{165}$ Epstein, supra note 91, at 956-57.

${ }^{167}$ See id. at $962-77$ (discussing the employer's ability to monitor employee behavior, reputational losses, risk diversification, imperfect information, administrative costs, bilateral monopoly, and unequal bargaining power as reasons why the at-will contract usually benefits both sides in employment contexts).

${ }^{169}$ Id. at 957. 
simply assumed from its survival and frequency in contracting practice. The analysis purports only to explain why people might rationally choose to behave in this manner; it does not claim to establish that social wealth is actually greater than it would be under a regime of job security. A particular notion of human rationality and evolutionary process ${ }^{169}$ substitutes for rigorous cost-benefit comparison grounded in empirical research. ${ }^{170}$ The only empiricism here is the observation that at-will employment is prevalent, at least in this country. ${ }^{171}$

Although systematic empirical investigation of the respective costs and benefits of at-will versus job-security contract terms has yet to be undertaken, recently collected empirical data do cast significant doubt on Epstein's simple faith in the efficiency of the at-will contract term. Professor Kim's findings strongly suggest that workers employed on an at-will basis typically believe that they possess a significantly greater degree of job security than the law actually accords. ${ }^{172}$ This misperception, if it is as pervasive as Kim's data indicate, ${ }^{173}$ chal-

${ }^{169}$ See supra note 163.

${ }^{170}$ Commenting on Epstein's article, Professor Rosen, a University of Chicago economist, expresses appreciation for the analysis, but concern about the lack of empirical support. Acknowledging that the prevalence of at-will employment contracts suggests that it may be more efficient than alternative mechanisms for enforcing parties' implicit understandings, he nevertheless writes that "one might rest easier with some confirming numerical calculations of the costs and benefits." Sherwin Rosen, In Defense of the Contract at Will, 51 U. CHI. L. REV. 983, 987 (1984). In fact, an emerging body of empirical research suggests that job security can generate productivity increases. See supra note 89 . In light of such findings, the persistence of at-will employment may be due to reasons other than superior efficiency. Part III.B. 4 discusses how this could be the case.

${ }^{171}$ For an empirical study demonstrating the prevalence of at-will employment, see Verkerke, supra note 165, at 863-69 (discussing survey results showing that only $15 \%$ of employment contracts include a job-security term). In this respect, the United States is unusual. For example, through various legal and nonlegal mechanisms, Japan, Germany, Sweden, and the United Kingdom all provide job security for workers. See Summers, supra note 56, at $1038-57$ (discussing the various systems used by these countries to provide job security).

${ }^{172}$ See Pauline T. Kim, Bargaining with Imperfect Information: A Study of Worker Perceptions of Legal Protection in an At-Will World, 83 CORNELL L. REV. 105, 133-46 (1997) Kim's study relies on a survey of 337 unemployment insurance claimants. See id. at 129.

${ }^{173} \mathrm{Kim}$ found that as many as $80 \%$ or more of those surveyed believed incorrectly that Missouri law forbade discharge for various reasons that are in fact lawful. See id. at 134 tbl.1. Important as Kim's data are, Professor Verkerke points out that further research might involve recently hired rather than recently terminated workers, whose survey responses might be colored by their experience. See J. Hoult Verkerke, Emplojment Contract Law, in THE NEW PALGRAVE DICTIONARY OF ECONOMICS AND THE LAW (forthcoming 1998) (manuscript at 11, on file with author). 
lenges the efficiency assumption. If workers possessed full information about the legal significance of at-will employment, they presumably would value the at-will contract term less highly than they do and would place a higher value on a job-security term. If so, they might be more willing than they apparently are now to insist on job security. Even if they did not value job security that much more highly, employment contracts presumably would include additional compensation reflecting the greater risk of discharge to which workers are subject. ${ }^{174}$ The existence of significant informational deficits undermines the orthodox presumption of the status quo's efficiency. If the efficiency of observed behavior cannot be taken for granted, current arrangments do not deserve default-rule status simply because people tend to choose them. The next subparts consider why contracting practices may persist despite the possibility of superior alternatives.

\section{Path Dependency}

Until recently, little attention has been paid to the mechanisms that determine choice of contract terms. Now, however, the assumption that efficiency determines the status quo may no longer be tenable. Recent law-and-economics research on the theory of path dependency suggests that historical circumstance, rather than efficiency alone, shapes current contracting practices. ${ }^{175}$ Once a particular contract term has become standard, there may be reasons for its continued use that are unrelated to its intrinsic value. ${ }^{176}$

Professor Roe analogizes choices about legal rules and social institutions or practices to choices about the location of paths leading from one point to another. ${ }^{177}$ People make such choices for reasons that are sensible at the time. Thereafter, the chosen path becomes

${ }^{174}$ Verkerke's survey of 221 employers in five states found that only $15 \%$ expressly agreed to discharge workers for just cause only. See Verkerke, supra note 165, at 86567. Verkerke concludes that these data present "the best available evidence of [employers' and employees'] preferences" and therefore justify the current at-will default as providing the contract term that the parties typically would choose for themselves. Id. at 897. However, as Kim points out, Verkerke's data do not necessarily support his normative conclusion, because contracting practices may reflect the informational deficit that Kim has identified. See Kim, supra note 172, at 122-24.

${ }^{175}$ See F. Hodge O'Neal Corporate and Securities Law Symposium: Path Dependence and Comparative Corporate Governance, 74 WASH. U. L.Q. 317 (1996); Mark J. Roe, Chaos and Evolution in Law and Economics, 109 HARV. L. REV. 641 (1996).

${ }^{176}$ See infra Part III.B.4.

17 See Roe, supra note 175 , at $643-44$. 
established and then entrenched through ongoing usage. At some point, the community might be better off abandoning the existing path and building a new one, because a new path may provide a cheaper way of getting from point to point. However, there are benefits to retaining the standard route; it must be working reasonably well or people would not be using it. Further, the costs of building the new path may be greater than the benefits of doing so. ${ }^{178}$ It might even be the case that change is impossible because information about the superior alternative does not exist. ${ }^{179}$ Under such circumstances, the old path continues to prevail despite the possibility of a better way. ${ }^{180}$

The history of at-will employment in this country reveals that the practice arose in the context of particular economic conditions that no longer exist. The standard story describes the at-will presumption as a nineteenth-century invention. ${ }^{181}$ Professor Feinman attributes the rule's adoption to treatise writer Horace Wood. ${ }^{182}$ According to

${ }^{178}$ Roe refers to this phenomenon as "semi-strong form path dependence." Id. at 648-50.

${ }^{179}$ Roe has noted:

If a society cannot think effectively about the alternative path because it lacks the vocabulary, concepts, or even belief that the other path could exist, then that society cannot consciously choose either to return to the branch point of the two paths (and then go down the other path) or to jump to the other path.

Id. at 651. Roe refers to this situation, in which the existing practice is less efficient than the alternative, as "strong-form path dependence." Id. at 651-52. In addition to the strong and semi-strong forms, Roe also identifies a "weak" form of path dependence, by which he means a historical choice between one of two paths that would be equally efficient. History may explain the origins of the existing practice, but it tells us nothing about the present relative efficiency of the two alternatives. See id. at 647-48.

${ }^{180}$ An example of this phenomenon may be the "QWERTY" order on a typewriter keyboard. This arrangement, which uses weaker fingers for the more common letters, originated in the 19th century because typewriter keys jammed easily and the "QWERTY" order kept typists from working too quickly. The arrangement is no longer necessary today, but it persists nonetheless. See W. Brian Arthur, Competing Technologies, Increasing Retums, and Lock-In by Historical Events, 99 ECON. J. 116 (1989); Paul A. David, Understanding the Economics of QWERTY: The Necessity of History, in ECONOMIC HISTORY AND THE MODERN ECONOMIST 30 (William N. Parker ed., 1986).

${ }^{181}$ See, e.g., ROTHSTEIN ET AL., supra note 41 , at 10 (noting that " $[\mathrm{b}] \mathrm{y}$ the end of the nineteenth century, most American courts began to apply a presumption of terminability at will").

${ }^{182}$ See Jay M. Feinman, The Development of the Employment at Will Rule, 20 AM. J. LEGAL HIST. 118, 126 (1976); see also HORACE G. WOOD, A TREATISE ON THE LAW OF MASTER AND SERVANT (2d ed., San Francisco, Bancroft-Whitney Co. 1886). 
Feinman, Wood made it up in 1877 out of whole cloth. ${ }^{183}$ Before 1877, American courts supposedly followed English law, which presumed that employment was for a one-year term if the contract was silent on the question of duration. ${ }^{184}$

Recent research rejects this account and argues instead that the American presumption of at-will employment dates back to the colonial period. ${ }^{185}$ Professor Ballam focuses on Maryland, Massachusetts, New York, and Pennsylvania as case studies. She relies on nonlegal sources such as newspaper advertisements and other historical information on employment practices, as well as statutory and caselaw data. ${ }^{186}$ Ballam concludes that employment at will was the usual practice among free laborers, both industrial and agricultural, in the four states she examined ${ }^{187}$ and, by implication, more generally in the antebellum United States as well.

Specific labor market conditions led employers and workers to reject the English presumption of annual hiring in favor of a presumption that better reflected the preferences of both workers and employers. Extreme labor scarcity meant that competition among employers accorded workers a range of job opportunities. ${ }^{188}$ The ready availability of land and burgeoning industry in towns encouraged a high degree of worker mobility. ${ }^{189}$ Under these circumstances, workers valued the freedom to quit at any time, and had the market leverage to insist on it. Employers, too, preferred flexibility, because many agricultural and industrial activities were seasonal. In addition,

${ }^{183}$ See Feinman, supra note 182, at 126 ( $[$ [I]n the absence of valid legal support, Wood offered no policy grounds for the rule he proclaimed."). Responding to Feinman, Professors Freed and Polsby identify some pre-1877 evidence of adoption of employment at will by American courts, but not much. See Mayer G. Freed \& Daniel D. Polsby, The Doubtful Provenance of "Wood's Rule" Revisited, 22 ARIZ. ST. L.J. 551, 554-56 (1990) (discussing four cases, only two of which clearly involve employment at will). More recently, Professor Morriss traces the endorsement of an at-will rule in various American jurisdictions. Almost all of the cases he cites were decided after 1870, and, according to Morriss's research, 22 states did not formally adopt the rule until the 20th century. See Andrew P. Morriss, Exploding Myths: An Empirical and Economic Reassessment of the Rise of Employment At-Will, 59 MO. L. REV. 679, 699 tbl.I (1994).

${ }^{184}$ See 1 William BlaCKSTONE, COMMENTARIES *413 ("If the hiring be general without any particular time limited, the law construes it to be a hiring for a year....").

${ }_{185}$ See Deborah A. Ballam, The Traditional View on the Origins of the Employment-At-Will Doctrine: Myth or Reality?, 33 AM. Bus. L.J. 1 (1995).

${ }^{185}$ See id. at 5-6.

${ }^{187}$ See id. at 47 (" $[E] m p l o y m e n t-a t-w i l l$ was always the standard in these four states, for all classes of laborers ....").

${ }^{189}$ See id. at 8.
See id. 
recurring depressions necessitated the freedom to lay off workers during periods of reduced demand. Labor market conditions peculiar to eighteenth- and nineteenth-century America explain the prevalence of employment at will in this country at that time.

As Ballam's study of the caselaw demonstrates, in the absence of an express contractual term, courts presumed that employment was on an at-will basis. ${ }^{190}$ If employers sought to bind a worker to a specific term of employment, the contract had to specify its duration. Labor mobility made it difficult to enforce such agreements, but contracting practice reveals an awareness that an express term was necessary to avoid the default rule. ${ }^{191}$ Presumably, at-will became the default rule because it was the term that most parties would prefer if they had to make a choice between employment at will and job security. ${ }^{192}$

\section{Could Job Security Be More Efficient Today?}

Historical research indicates that employment at will became common in the context of particular social and economic circumstances. Path-dependency theory could explain its persistence even if changes in the economy have rendered it less efficient than job security. Current prevalence, therefore, does not necessarily indicate efficiency.

Since the nineteenth century, job opportunities have become less numerous and labor market competition has increased. Under such conditions, workers presumably would value stable employment more highly than they would in an environment offering more extensive employment opportunities. The risk of long-term unemployment, not faced in the colonial period, may also encourage workers to value job security.

${ }^{190}$ See id. at 10-14, 21-26, 31-35, $39-42$ (discussing treatment of employment disputes by courts in Massachusetts, New York, Pennsylvania, and Maryland, respectively).

${ }^{191}$ In contrast, the English presumption of a year's duration seems to have been based on an oversupply of labor and concerns about the burdens that the unemployed imposed on the poor relief system. See id. at 48 .

${ }^{192}$ According to Ballam, court decisions from the later-19th and early-20th centuries, which have been cited as indicating a novel departure from prior law, turn out to have had a much more narrow import. Rather than adopting an at-will presumption, which was already part of the law, they adopted the rule that salary stated in terms of a fixed rate per time period implied an agreement to employ a worker for that length of time. See id. at 49. Courts also accepted the rule that a worker who had contracted to work for a specific time period and had stayed on after expiration of that period had an implied right to renewal of that fixed term. See id. 
With the rise of large-scale industrial production, increasing complexity and task specialization may require workers to make larger investments in training to be successful on the job. To the extent such human-capital investments are firm-specific and, therefore, subject to forfeiture if workers lose their jobs, workers again would tend to place a higher value on job security than in previous periods.

Changed circumstances may also subject workers to a heightened risk of employer opportunism. As discussed above, employers stand to gain if they can fire workers in order to renege on implicit promises of deferred compensation. ${ }^{193}$ In the past, reputational considerations may have moderated such behavior in localized labor markets in which employer behavior was widely known. In contrast, prospective workers may have less access to information about employers in today's larger-scale, less personal economy. ${ }^{194}$ To the extent this is so, at-will employment imposes costs on workers that they may not have had to bear in the early-nineteenth century.

Employers, too, may stand to benefit from employee job security. Promises of long-term employment may be necessary to induce workers to make upfront investments in value-creating, firm-specific human capital. ${ }^{195}$ Long-term job security may also encourage worker loyalty and higher productivity. ${ }^{196}$ A stable workforce also obviates the disruption that can occur when training newly hired workers.

As compared with at-will status, job security may increase the likelihood of shirking behavior; under an at-will regime, the employer need not bear the burden of proving cause in order to fire a worker who is not living up to her end of the bargain. ${ }^{197}$ Even so, it is possible that the gains generated by job security could outweigh such costs. Perhaps we now live in a world in which both employers and workers would be better off under job-security contract terms than under employment at will. At the very least, vastly changed circumstances should lead us to question whether at-will employment serves as well

193 See supra notes 25-28 and accompanying text.

${ }^{194}$ See Note, supra note 28 , at 524 ("The usual job searcher cannot easily obtain information about a firm's personnel relations.... In addition, firms may project a false image of job security.").

${ }^{193}$ For a discussion of this function of lifetime employment in the Japanese firm, see Masahiko Aoki, Toward an Economic Model of the Japanese Firm, 28 J. ECON. LITERATURE 1 (1990).

${ }_{196}$ See supra note 89. will).

${ }^{197}$ See Epstein, supra note 91 , at 970 (discussing the cost advantages of a contract at 
today as it did at the time of its original adoption in this country nearly two centuries ago. As Roe cautions, "when we identify current structures that were path-determined by forces irrelevant to today's world, we should not accord the current rule or institution a presumption of utility." 198

\section{Why Does At-Will Predominate?}

Even if the origins of at-will employment can be traced to economic circumstances that no longer exist, why have workers and employers not moved from that path to a new one, if the new one would better serve their interests? Persistent use of the old path cannot simply be due to the fact that at-will employment is the default rule. If job security were more efficient, we would expect parties to employment contracts to adopt that term instead, barring prohibitive transaction costs.

Drawing on recent research in economics and behavioral psychology, Professors Kahan and Klausner cast significant doubt on the presumption that the status quo necessarily owes its existence to superior efficiency. ${ }^{199}$ Rather, they argue, "one must look closely at particular contract terms and at their origins before reaching any conclusions about why a standard term exists." ${ }^{200}$ They offer several explanations for the persistence of standard terms, even though a novel term might yield greater value.

\section{a. Network Benefits}

Economists first developed the concept of network benefits or network externalities in the context of product standardization. ${ }^{201}$ Certain products increase in value as their use becomes more widespread. For example, VCRs became more useful as more and more videocassettes became available, as did personal computers as soft-

198 Roe, supra note 175 , at 667.

199 See Marcel Kahan \& Michael Klausner, Path Dependence in Corporate Contracting: Increasing Returns, Herd Behavior and Cognitive Biases, 74 WASH. U. L.Q. 347 (1996) [hereinafter Kahan \& Klausner, Path Dependence]; see also Marcel Kahan \& Michael Klausner, Standardization and Innovation in Comporate Contracting (or "The Economics of Boilerplate"), 83 VA. L. REV. 713 (1997); Klausner, supra note 10.

${ }^{200}$ Kahan \& Klausner, Path Dependence, supra note 199, at 349.

${ }^{201}$ See, e.g., Joseph Farrell \& Garth Saloner, Installed Base and Compatibility: Innovation, Product Preannouncements, and Predation, 76 AM. ECON. REV. 940 (1986); Michael L. Katz \& Carl Shapiro, Network Externalities, Competition, and Compatibility, 75 AM. ECON. REV. 424 (1985). 
ware products proliferated. Increased videocassette and software production, however, depended on increasing ownership of VCRs and personal computers constructed in a standard format. Standardization created value that otherwise would not have existed. ${ }^{202}$

Klausner's innovative insight was to apply the network externality idea to standardization of contract terms. ${ }^{203}$ A widely used contract term may result in greater value for its users than the term would yield if it were used only occasionally. ${ }^{204}$ It is possible that these benefits may be sufficient to justify resorting to the standard term even though an alternative might otherwise be more efficient.

One benefit of standardization is the accumulation over time of a body of judicial interpretation, resulting in a more concrete, determinate meaning than a nonstandard term would enjoy. The availability of a standard term with a more or less definite meaning also creates a bias in its favor because the costs of adopting the standard term are significantly lower than choosing an alternative. Parties who desire the typical contract provision can simply adopt the standard term. In the employment context this is particularly easy, because contractual silence incorporates the at-will default rule. In contrast, parties seeking to include a job-security term would confront the costs of drafting appropriately specific language. This can be a timeconsuming process, especially because there is uncertainty as to how courts will interpret novel language.

Contracts reflecting settled practice and being offered on a takeit-or-leave-it basis also have the advantage of avoiding the costs of ad hoc bargaining. ${ }^{205}$ In the employment context, such costs can be especially significant because uncertainty about the costs and benefits of a novel job-security contract term compounds already difficult valuation problems. Employment contracts differ from sales contracts in an important respect: Rather than purchasing a good, the employer hires an agent whose value depends on her future effort. ${ }^{206}$ Likewise, the value of an employment opportunity to a worker depends in part on the employer's future behavior toward the worker.

${ }^{202}$ See Kahan \& Klausner, Path Dependence, supra note 199, at 351.

${ }^{203}$ See Klausner, supra note 10, at 774 ("Although corporate contract terms do not entail technological connectivity as computers, telephones and other network products do, analagous benefits of standardization exist.").

${ }^{204}$ See Kahan \& Klausner, Path Dependence, supra note 199, at 350-53 (discussing increasing returns from the standardization of contract terms).

${ }^{205}$ See Reder, supra note 46, at 247.

${ }^{205}$ See Herbert A. Simon, A Formal Theory of the Employment Relationship, 19 ECONOMETRICA 293, 294-95 (1951). 
Determining these future values is difficult for both parties because each party's assessment of value depends in large part on a prediction about the other party's future behavior. Behavior varies among both workers and employers according to various idiosyncratic personality traits. Some people work harder than others, and some employers are more trustworthy than others. ${ }^{207}$ Market conditions, such as competitive pressures or opportunities that give employers or workers more or less freedom to behave opportunistically, may also affect future behavior.

In a competitive labor market in which at-will is the standard term, the going wage for a particular job embodies a collective judgment grounded in experience about the costs and benefits of that contract term. Among other considerations, the wage incorporates assessments by both workers and employers of aggregate data on the likelihood that the other party to the contract will behave opportunistically. Departures from the going wage are likely to occur only in exceptional cases, in which reliable information about a particular worker's or employer's trustworthiness is available. In contrast, if one or both of the parties want to substitute a job-security term, each must make a judgment about its likely costs and benefits in order to recalculate the wage. Rather than relying on the market's determination, the parties now must make predictions both about each other's and their own future behavior, and about future market conditions. This is difficult enough, but, as noted already, there is the added difficulty of predicting how a court will interpret the novel contract term in various possible future contexts. The very commonness of the at-will term involves potential contracting gains that are not available to parties seeking to contract on a job-security basis.

In short, the benefits that accrue to standardization may be sufficient to outweigh the benefits that both workers and employers could realize by shifting to a job-security regime. Even if an at-will contract term-shorn of any network benefits-were less valuable to the parties than job security would be, shifting to a job-security regime would entail loss of these benefits. Such losses may be large enough to keep people on the well-worn at-will path.

${ }^{207}$ See supra note 162 (noting that it may be difficult for employers to distinguish between high-effort and low-effort employees at the time of hiring). 


\section{b. Herd Behavior}

Economists have developed the "herd behavior" theory to explain a tendency of decisionmakers to mimic the behavior of others, even when it might seem that rational reliance on private information should yield a different choice. ${ }^{208}$ According to one herd behavior model, the reputational costs that come with decisions that turn out badly are lower if the actor was simply following standard practice than they would be if she was acting innovatively. ${ }^{209}$ If, for example, investment managers make investment decisions that prove to be losers, their superiors are less likely to deem them foolish if they were following the decisions of others rather than acting in a contrarian manner. ${ }^{210}$ Professors Sharfstein and Stein posit that this is because smart managers are assumed to behave alike; what makes them "smart" is their shared ability to identify truthful information about the wisdom of particular investment choices. Contrarians, therefore, are more likely to be perceived as foolish precisely because they have failed to follow the herd. ${ }^{211}$

Kahan and Klausner apply the herd behavior idea to contracting to suggest a similar tendency among agents to prefer standard terms when contracting on behalf of principals. ${ }^{212}$ Their discussion focuses on the incentives against innovation that lawyers face when drafting contracts for clients. The key idea is the potential conflict of interest generated by the lawyer's reputational concerns, which may lead the lawyer to imitate the actions of other lawyers even when faced with information that ought to counsel a novel course of action. ${ }^{213}$

${ }^{203}$ See David S. Scharfstein \& Jeremy C. Stein, Herd Behavior and Investment, 80 AM. ECON. REV. 465 (1990) (discussing how group psychology may affect investment decisions by fund managers); Jeffrey Zweibel, Corporate Conservatism and Relative Compensation, 103 J. POL. ECON. 1 (1995) (same).

${ }_{209}$ See Scharfstein \& Stein, supra note 208.

${ }^{210}$ See id. at 466 (noting that "an unprofitable decision is not as bad for reputation when others make the same mistake").

${ }^{211}$ See id. Scharfstein and Stein refer to this phenomenon as a "sharing-the-blame" effect. Id.

${ }^{212}$ See Kahan \& Klausner, Path Dependence, supra note 199, at 353-58.

213 Kahan and Klausner's discussion of herd behavior among attorneys, see id. at 355-58, draws on Scharfstein and Stein's analysis, see supra notes 208-11 and accompanying text. Kahan and Klausner also discuss other reasons why reputational concerns may lead lawyers to favor standard contracting practice over innovation. Lawyers, vulnerable to reputational costs if a contract does not accomplish the client's objectives, may be less willing than clients would be to assume the risk of uncertainty of outcome that a novel contract term presents. See Kahan \& Klausner, Path Dependence, supra note 199, at 354 ("To the extent that a lawyer cannot diversify career risk, lawyers 
The herd behavior idea may be pertinent to a broad range of contracting situations. ${ }^{214}$ In the employment sphere, nonunion workers generally act on their own behalf. Firms, however, must act through agents, who are concerned not only with their employers' interests, but also with their own reputations. Thus, even if the agent believes that the expected value of using a job-security contract term is greater than that of contracting on an at-will basis, the higher costs associated with failure may be sufficient to encourage resort to the standard term instead. A job-security term, therefore, would come at a higher price than would be the case if at-will were not the standard term. Herd behavior makes use of the at-will term more likely than would be the case if job security were the standard term, and is another reason why persistent resort to the at-will contract term may not be a function of its superior efficiency.

\section{c. Cognitive Biases}

Behavioral psychology research also may help to explain why a standard contract term could be less efficient than an alternative. Kahan and Klausner focus particularly on status quo bias and the endowment effect, anchoring bias, and conformity bias. ${ }^{215}$

As discussed above, investigators have found that people faced with choices about how to spend resources tend to favor existing patterns of expenditure over alternatives. ${ }^{216}$ In contractual settings, Kahan and Klausner conjecture that people tend to view the standard contract term as the status quo. ${ }^{217}$ Thus, the fact that employment contracts are typically on an at-will basis may create a bias among workers and employers alike in favor of at-will employment. When, as in this context, the standard contract term is also the default rule, it seems plausible that the bias in its favor may be even stronger. The fact that the contract need say nothing in order to elect the standard

will frequently be more risk averse than their clients."). Kahan and Klausner also suggest that, even if lawyers are not more risk averse than clients, failure may weigh more heavily than success on a lawyer's reputation, causing lawyers to favor standard contract terms that have a lower range of possible outcomes than nonstandard terms. See id. at 354-55 ("[A] contract term that fails ... may weigh more heavily in a lawyer's reputational payoff than a contract term that succeeds.").

${ }^{214}$ See Kahan \& Klausner, Path Dependence, supra note 199, at 356 (pointing out that reputational costs of innovation could arise in many contracting situations).

${ }^{215}$ See id. at 359-64.

${ }^{216}$ See supra Part II.B.1.

${ }^{217}$ See Kahan \& Klausner, Path Dependence, supra note 199, at 361-62; see also Korobkin, Status Quo Bias, supra note 97, at 630-33. 
term may reinforce the sense that this is the usual way things are done. Status quo bias, if applicable to choices between standard and nonstandard contract terms, could provide a further reason why the pervasiveness of at-will employment encourages people to favor it over job security. ${ }^{218}$

Like status quo bias, the endowment effect leads people to prefer existing states of affairs over alternatives, even though they would prefer the alternative if endowed with it instead. As discussed above, the endowment effect appears to apply to contractual default rules as well as ownership of assets, even though default rules confer no rights in the absence of an agreement with another party. ${ }^{219}$ Because at-will is the default rule, employers enjoy the presumptive right to discharge members of their workforce. If the endowment effect is operative, employers may value that right more highly than they would if job security were the default and it were necessary to bargain and pay for the rights implicit in the at-will default rule.

Similarly, workers may value the wage premium that comes with at-will status more highly than they would if job security and a lower wage were the starting point for negotiations. In other words, the existence of the endowment effect in some settings allows us to hypothesize that workers and employers alike value the bundle of rights associated with employment at will more highly than they would if job security were the default rule and standard practice instead. Again, the status quo, simply by virtue of its existence, may generate a presumption in its favor that supplements any value it would otherwise enjoy.

Anchoring bias refers to the effect of initial reference points on judgments about value. ${ }^{220}$ In one study, real estate agents and lay

${ }^{218}$ See generally Korobkin, Status Quo Bias, supra note 97 (discussing status quo bias in relation to default rules).

${ }^{219}$ See supra Part II.B.2. As Kahan and Klausner put it, contracting parties "have no formal property (or other) rights in a standard term." Kahan \& Klausner, Path Dependence, supra note 199 , at 361 .

${ }_{220}$ See Gregory B. Northcroft \& Margaret A. Neale, Experts, Amateurs, and Real Estate: An Anchoring-and-Adjustment Perspective on Property Pricing Decisions, 39 ORG. BEHAV. \& HUM. DECISION PROCESSES 84, 85 (1987) (noting that psychological literature on anchoring "suggests that (a) an arbitrarily chosen reference point (anchor) will significantly influence value estimates, and (b) value estimates will be insufficiently adjusted away from the reference point toward the true value of the object of estimation"); see also S. Plous, Thinking the Unthinkable: The Effects of Anchoring on Likelihood Estimates of Nuclear War, 19 J. APPLIED SOC. PsYCHOL. 67, 70-71 (1989) (finding that estimates of likelihood of nuclear war depended on magnitude of initial reference point). 
people were asked to assess the value of a house. ${ }^{221}$ They were given listing prices that ranged from $\$ 119,900$ to $\$ 149,900$; both the students and the real estate agents inspected the house before being asked to assess its value. Those real estate agents who were told that the listing price was $\$ 119,900$ assessed the house's value at an average price of approximately $\$ 114,000$, while those who believed the listing price to be $\$ 149,900$ valued it at approximately $\$ 129,000$. $^{222}$ Similarly, the students valued the house at an average price of approximately $\$ 117,000$ when provided with the low listing price and at approximately $\$ 144,000$ in response to the high one. ${ }^{2}$

Kahan and Klausner suggest that standard contract terms may have a similar anchoring effect because they carry with them "an aura of stability and objectivity." 224 The fact that the at-will doctrine is not only the standard term but also the default rule may strengthen this effect. If so, the at-will default, acting as an anchor, may cause workers and employers to gravitate toward it more readily than they would if it did not provide a reference point for contract negotiations. They may value it more highly because it is the standard term than they would if it were not.

\section{d. Myopia}

In addition to the phenomena discussed by Kahan and Klausner, there may be yet another psychological predisposition or bias in favor of at-will employment. Professor Elster suggests that myopia may be at work when people are unwilling to choose courses of action with short-term costs despite superior long-term benefits. ${ }^{225}$

A worker or an employer contemplating switching from the at-will default to a job-security regime would incur predictable short-term costs. From the worker's perspective, there would be search costs in identifying those employers willing to depart from the standard at-will

221 See Northcroft \& Neale, supra note 220, at 92.

${ }^{222}$ See id. at 93.

223 See id.

224 Kahan \& Klausner, Path Dependence, supra note 199, at 363.

${ }^{225}$ See Jon Elster, Self-Realisation in Work and Politics: The Marxist Conception of the Good Life, 3 SOC. PHIL. \& POL'Y 97 (1986), reprinted in ALTERNATIVES TO CAPITALISM 127, 138 (Jon Elster \& Karl Ove Moene eds., 1989) ("The fact that self-realisation involves deferred gratification ... must enter importantly into the explanation of why it is not chosen even when its superiority is clearly recognised."); see also Cass $\mathrm{R}$. Sunstein, Legal Interference with Private Preferences, 53 U. CHI. L. REv. 1129, 1164-66 (1986) (discussing " $t$ the phenomenon of myopia-refusal to engage in an activity with high long-term benefits because of its short-term costs"). 
contract term to bargain to a job-security outcome. Employers considering hiring workers on a job-security basis would have to undertake more elaborate screening efforts to reduce the costs imposed by restraint on their freedom of discharge, and workers would incur signaling costs as they attempted to demonstrate ex ante their reliability. ${ }^{226}$ Workers and employers also would have to draft an appropriately complete and specific contract term, a task made more difficult by the absence of standard language that has acquired determinate meaning through recurrent judicial interpretation. This cost is likely to appear especially weighty when compared with the elegant simplicity of the at-will doctrine, which has "the convenient virtue of meaning just what it says, no more and no less." ${ }^{227}$ In the absence of a market price, efforts to price a novel contract term are also likely to require time-consuming bargaining.

The myopia phenomenon could lead workers and employers confronted with such costs to reject the job-security alternative even if it promised greater long-term benefits. According to Elster, it is the temporal sequence of cost before benefit that seems to breed "weakness of the will" under certain circumstances. ${ }^{228}$ Well-known examples include unwillingness to take the difficult steps necessary to quit smoking cigarettes despite the known long-term health benefits, or refusal to wear uncomfortable safety belts while driving despite the promise of significant protection in the event of an accident. Even when there can be no doubt about the net benefits of making a change, people sometimes seem unwilling to make the required efforts. Similar behavior could be at work in the employment contract setting as well.

I suspect there may be more to myopia than simply the sequence of cost and benefit. It may be that known short-term costs interfere with the ability to make accurate valuations of long-term benefits. Especially where the long-term gains are genuinely difficult to measure, the existence of more definite short-term costs may create cognitive "static." For example, a smoker who knows that quitting will be very unpleasant might be unable to comprehend fully the less concrete benefits that it will eventually bring. Similarly, workers and employers, aware of the difficulties of contracting around the at-will default, may be incapable of fully grasping the benefits of job security.

${ }^{226}$ See supra note 162 (discussing signaling as a response to employer inability to discriminate between high-and low-effort employees).

${ }_{227}^{22}$ Epstein, supra note 91, at 955.

${ }_{223}$ Elster, supra note 225, at 138. 
Inability to appreciate the value of innovation may be even more likely when the existing practice enjoys a long history and has worked at least tolerably well. This analysis suggests a cognitive dimension to myopia as well as a behavioral one.

\section{e. Sour Grapes}

The phenomena indicating a preference for the status quo over possible alternatives may also reflect a general tendency to value what we have more highly than we would if we did not have it and, correspondingly, to value less highly what we do not have. This is the "sour grapes" idea described by Elster. ${ }^{229}$ Orthodox economic analysis takes peoples' preferences as given or exogenous to social contexts. ${ }^{230}$ Elster responds that preferences may be shaped by peoples' perceptions of what is reasonably available to them. ${ }^{231}$ In this sense, preferences may be endogenous. Like the fox in the fable who suddenly developed an aversion to grapes that it realized it could not reach, ${ }^{232}$ people who perceive that certain alternatives are beyond their grasp may prefer more readily available choices for that reason alone. In other words, preferences are derived from the circumstances in which people find themselves.

According to Elster, the sour grapes phenomenon reduces cognitive dissonance by reducing frustration that would otherwise arise from the boundedness of the set of feasible choices. ${ }^{233}$ However, it may be that people's preferences adapt not only to perceptions of what is and is not available, but also to what they possess. Thus, people's preferences may be shaped by a tendency to value what they have, and a corresponding tendency to devalue what they do not have. Even if alternatives are available, the advantages and disadvantages of existing patterns of behavior are likely to be familiar and reasonably well understood. Change, in contrast, involves investigation and evaluation of alternatives that threaten uncertain conse-

${ }^{229}$ See JON ELSTER, SOUR GRAPES 109-40 (1983).

${ }^{250}$ See, e.g., George J. Stigler \& Gary S. Becker, De Gustibus Non Est Disputandum, 67 AM. ECON. REV. 76, 76 (1977).

${ }^{231}$ See ELSTER, supra note 229, at 121-22; see also Jon Elster, From Here to There: Or, If Cooperative Ownership Is So Desirable, Why Are There So Few Cooperatives?, 6 Soc. PHIL. \& POL'y 93, 96 (1989) (suggesting that prevalence of capitalist over cooperative business ownership may be due in part to endogenous preference formation). For a discussion of the implications of adaptive preferences for legal policy, see Sunstein, supra note 225, at 1145-50, 1169-74.

${ }_{232}$ See ELSTER, supra note 229, at 109.

${ }^{233}$ See id. at 110. 
quences. People appreciate existing behaviors and social systems, in part, because they function as reference points, while alternatives look worse simply by virtue of their status as such. ${ }^{234}$

The tendency of preferences to adapt to the status quo could explain a general preference for at-will employment, even if people would prefer job security if at-will employment were not the norm. Unlike the grapes in the fable, a job-security contract term is not literally beyond the reach of those who might want it. Nevertheless, the fact that employment at will is the standard practice may itself suggest that a job-security contract term is not a realistic alternative, and its status as the default rule may imply the same message. In a similar vein, Elster suggests that adaptive preferences may explain a general reluctance among workers to form or to join cooperatively owned firms, even though there is no legal impediment to doing so. ${ }^{235}$ Perhaps more importantly, there are genuine costs involved in negotiating for a job-security term, making it less attractive than at-will employment for that reason alone. Furthermore, inexperience with the benefits of job security and uncertainty about the magnitude of its cost (in the form of reduced wages) may also encourage higher valuation of the familiar at-will contract term.

$$
* * * *
$$

In this Part, I have argued that a path-dependency understanding of employment at will as a practice and as a default rule suggests that its current prevalence does not necessarily indicate superior efficiency. Employment at will may have made sound economic sense at the time of its adoption in this country. ${ }^{236}$ It became the dominant practice. Nevertheless, there are plausible reasons why at-will employment might continue to predominate even if it is no longer superior to job security. Some of these reasons involve genuine-that is, objectively identifiable-economic benefits. A history of settled practice confers value on a contract term by virtue of its widespread acceptance. Other reasons for at-will's predominance may have a more purely subjective or psychological dimension. There may be

294 The similarities between Elster's "sour grapes" idea and the endowment effect and status quo bias should be apparent.

${ }^{235}$ See Elster, supra note 231, at 109-10 ("It is a truism, but an important one, that workers' preferences are to a large extent shaped by their economic environment. Specifically, there is a tendency to adaptive preference formation, by which the actual mode of economic organization comes to be perceived as superior to all others.").

${ }^{226}$ Even that choice was path-dependent. People do not make abstract cost-benefit choices about their practices or institutions. Such choices are always embedded in a particular historically conditioned context. 
behavioral or cognitive barriers that tend to bolster the status quo. And, even if job security would now better suit both workers and employers, the costs involved in discovering and evaluating those potential gains may be prohibitive, preventing full appreciation of alternatives despite their feasibility.

I am not arguing here for the superior efficiency of employment on a job-security basis. Rather, my point is that at-will's predominance should not be taken as a measure of its superiority. The question of the efficiency of the status quo appears to be far more complex and uncertain than previously has been appreciated, and it should no longer be taken as an article of faith. It may be that the status quo can lay claim to a presumption of efficiency, though the question of where the burden of proof should lie requires research yet to be undertaken. If the relative efficiency of at-will employment is uncertain, the current prevalence of at-will should not by itself provide a sufficient reason to retain its default-rule status. As discussed above, there are potential distributive gains to be realized by changing the default rule to job security. ${ }^{237}$ At-will employment's presumed superior efficiency is too uncertain to warrant hesitation for that reason alone.

\section{CONCLUSION}

Corporate law's commitment to shareholder wealth maximization can be costly for nonshareholders. Communitarians have rejected the mainstream contractarian view that self-protection through contract is the appropriate response. The reasons for this rejection have not always been articulated clearly, but I believe the core concern should be the fact that wealth constraints inevitably limit the ability of many nonshareholders to bargain and pay for adequate safeguards. Because I have doubts about the adequacy of existing law reform proposals in a communitarian vein, I have presented a new law reform approach in this Article. Recent economic research strongly suggests that nonshareholders-workers have been the focus herecould benefit from a change in the existing contractual default rule from employment at will to job security. The ambition is not necessarily to usher in a new era of lifetime employment in this country. Rather, the aim is to improve bargaining outcomes by making it possible for workers to capture a larger share of the gains from trade,

${ }^{237}$ See supra Part II. 
regardless of whether actual contracts end up including at-will or jobsecurity provisions. For a number of reasons, at-will employment's pervasiveness is an inadequate indication of its superior efficiency and therefore does not justify retaining the at-will default rule. 
$* * * * * * * *$ 